\title{
Gene Expression and Molecular Characterization of a Xylanase from Chicken Cecum Metagenome
}

\author{
Hind AL-Darkazali, ${ }^{1,2}$ Vithaya Meevootisom, ${ }^{1}$ \\ Duangnate Isarangkul, ${ }^{1}$ and Suthep Wiyakrutta ${ }^{1}$ \\ ${ }^{1}$ Department of Microbiology, Faculty of Science, Mahidol University, Ratchathewi, Bangkok 10400, Thailand \\ ${ }^{2}$ Chemical and Petrochemical Research Center, Commission for Research and Industrial Development, \\ Ministry of Industry and Minerals, 10068 Baghdad, Iraq \\ Correspondence should be addressed to Suthep Wiyakrutta; suthep.wiy@mahidol.ac.th
}

Received 21 March 2017; Revised 15 May 2017; Accepted 23 May 2017; Published 2 July 2017

Academic Editor: Hugh W. Morgan

Copyright (C) 2017 Hind AL-Darkazali et al. This is an open access article distributed under the Creative Commons Attribution License, which permits unrestricted use, distribution, and reproduction in any medium, provided the original work is properly cited.

A xylanase gene $x y n A_{M G 1}$ with a 1,116-bp open reading frame, encoding an endo- $\beta$-1,4-xylanase, was cloned from a chicken cecum metagenome. The translated $\mathrm{XynA}_{\mathrm{MG} 1}$ protein consisted of 372 amino acids including a putative signal peptide of 23 amino acids. The calculated molecular mass of the mature $\mathrm{XynA}_{\mathrm{MG} 1}$ was $40,013 \mathrm{Da}$, with a theoretical pI value of 5.76 . The amino acid sequence of $\mathrm{XynA}_{\mathrm{MG}}$ showed 59\% identity to endo- $\beta-1,4$-xylanase from Prevotella bryantii and Prevotella ruminicola and $58 \%$ identity to that from Prevotella copri. Xyn $\mathrm{A}_{\mathrm{MG}}$ has two conserved motifs, DVVNE and TEXD, containing two active site glutamates and an invariant asparagine, characteristic of GH10 family xylanase. The $x y n A_{M G 1}$ gene without signal peptide sequence was cloned and fused with thioredoxin protein (Trx.Tag) in pET-32a plasmid and overexpressed in Escherichia coli Tuner ${ }^{\mathrm{TM}}$ (DE3)pLysS. The purified mature $\mathrm{XynA}_{\mathrm{MG} 1}$ was highly salt-tolerant and stable and displayed higher than $96 \%$ of its catalytic activity in the reaction containing 1 to $4 \mathrm{M} \mathrm{NaCl}$. It was only slightly affected by common organic solvents added in aqueous solution to up to $5 \mathrm{M}$. This chicken cecum metagenome-derived xylanase has potential applications in animal feed additives and industrial enzymatic processes requiring exposure to high concentrations of salt and organic solvents.

\section{Introduction}

Microbial enzymes have been recognized as a major source of various types of biocatalysts which can be successfully applied in different industrial processes [1]. To be practically useful and economically competitive, industrial enzymes must display high activity and stability under harsh conditions to help reduce the production costs [2]. Carbohydrases, enzymes that degrade polymeric carbohydrates, are currently employed in various industries including food and beverages, detergent, biofuel production, textile, paper and pulp, leather industries, and animal feed. However, there are only two enzymes, xylanase and glucanase that dominate the global enzyme market by more than $80 \%[1,3]$.

Xylanases (endo-1,4-beta-xylanase; EC 3.2.1.8) are glycosidases which randomly cleave internal $\beta-1,4-\mathrm{D}$-xylosidic linkages of xylan [4], a bioheteropolymer consisting of
D-xylose homopolymer backbone that can be substituted to diverse degrees with glucuronosyl, 4-O-methyl-D-glucuronopyranosyl, $\alpha$-L-arabinofuranosyl, acetyl, feruloyl, and/or $p$-coumaroyl residues and is one of the most abundant polysaccharides in nature [5-7]. Complete depolymerization of xylan needs a synergistic action of several xylanolytic enzymes. Majority of the xylanases are confined either to glycosyl hydrolase family 10 (GH10) or to family 11 (GH11) based on similarities in their hydrophobic clusters and amino acid sequences of the catalytic domains. However, some are found in other glycosyl hydrolase families including $5,7,8$, $16,26,43,52$, and $62[4,8,9]$.

Generally, intestinal microorganisms of plant-eating animals are known to be excellent sources of various hydrolytic enzymes. Considering that poultry feeds consist mainly of cereal grains which are rich in nonstarch polysaccharides including xylans and arabinoxylans, microorganisms 
producing nonstarch polysaccharide hydrolases including xylanase should be abundant in chicken intestine. Chicken cecal microbiota has been shown, in a culture-based study, predominated by the phyla Bacteroidetes and Firmicutes [10]. However, majority of gut microorganisms are unculturable. Therefore, metagenomic strategy is used to recover the genes of desired enzymes [11]. Recently, a metagenomic study of chicken cecal microbiome showed that up to $1.5 \%$ of the sequences represented glycosyl hydrolase $(\mathrm{GH})$ domains with over two hundred different sequences of nonstarch polysaccharide-degrading enzymes found [12].

In this paper, we report the gene cloning, sequence and phylogenetic analyses, structural prediction, heterologous expression, and molecular and catalytic characterizations of a new GH10 family endo-xylanase derived from a chicken cecum metagenome.

\section{Materials and Methods}

2.1. Strains, Plasmids, and Chemicals. The Escherichia coli $\mathrm{EPI} 300^{\mathrm{TM}}-\mathrm{T}^{\mathrm{R}}$ clone harboring fosmid pCC1FOS carrying a chicken cecal metagenomic DNA fragment containing a xylanase gene was a gift from Dr Kenneth van Driel. All enzymes and dNTPs in this study were purchased from New England BioLabs Inc., USA, and Promega, USA. Plasmid DNA extraction and purification kit was purchased from GE Healthcare, UK. TALON Superflow Metal Affinity Resin (Clonetech) was purchased from TaKaRa (Otsu, Japan). The expression vector pET-32a (Novagen) was used for cloning and expressing the xylanase. E. coli Tuner (DE3)pLysS was used as expression host and was cultivated on Luria-Bertani medium (Difco). The enzyme substrates used were xylan from oat-spelt (Fluka), xylan from beechwood (Megazyme), $\alpha$-cellulose (Sigma), carboxymethyl cellulose (Sigma), starch (Sigma), $\beta$-glucan from barley (Sigma), 4-nitrophenyl- $\beta$-Dxylopyranoside (Megazyme), 4-nitrophenyl- $\beta$-D-cellobioside (Sigma), and 4-nitrophenyl- $\alpha$-D-galactopyranoside (Fluka). Molecular weight standard mix containing xylose, xylobiose, xylotriose, xylotetraose, xylopentaose, and xylohexaose (Megazyme) was the gift from Professor Khanok Ratanakhanokchai, KMUTT, Thailand. All other chemicals were obtained from Sigma-Aldrich (St. Louis, MO, USA).

\subsection{Bioinformatic Analysis of DNA and Amino Acid Sequen-} ces. Nucleotide sequence recognized as xylanase gene was translated into amino acids. Similar sequences were retrieved from the GenBank database using the BLAST search. Sequence alignment and phylogenetic analysis were done using the CLC Main Workbench 7.7 sequence analysis software package (CLC bio). To determine the family of the xylanase, the position of glutamate residues of the active site, and the highly conserved motifs of GH10, the ExPASyPROSITE (http:/www.expasy.org/prosite) was used. The signal peptide was predicted by using SignalP 4.1 server (http:// www.cbs.dtu.dk/services/SignalP). The theoretical pI and molecular weight were predicted using an online prediction tool (http://www.expasy.org/tools/pi_tool.html). The structure of $\mathrm{XynA}_{\mathrm{MG1}}$ protein was predicted using the
SWISSMODEL (https://swissmodel.expasy.org/) and IntFOLD (http://www.reading.ac.uk/bioinf/IntFOLD/) servers. Images were generated using PyMOL software (http://www .pymol.org/).

2.3. Construction of pET32a-Xyn $A_{M G 1}$ Plasmid, Gene Expression, and Purification of XynA $A_{M G 1}$ Xylanase. The xylanase gene $x y n A_{M G 1}$ was amplified by PCR from the pCC1FOS fosmid clones, using the Xyl524GH10CH-Fw: $5^{\prime}$-ATGAGCTCGCTGACACCC- $3^{\prime}$ forward and Xyl524GH10CH-Rv: $5^{\prime}$ CTAAGCTTGTCACTGCTTGAAC- $3^{\prime}$ reverse primers. The primer pair targeted the truncated gene, excluding the leader peptide encoding sequences, and introduced SacI and HindIII restriction sites at $5^{\prime}$ - and $3^{\prime}$-end of the gene. The amplified PCR product was digested with SacI and HindIII and ligated, using T4 DNA polymerase, into pET$32 \mathrm{a}(+)$ vector previously linearized with the same restriction enzymes and dephosphorylated with Antarctic Phosphatase (New England BioLabs). The expression plasmid $\left(\mathrm{pET} 32 \mathrm{a}-x y n A_{M G 1}\right)$, having the $x y n A_{M G 1}$ gene under the control of the T7 promoter, was used to transform chemically competent [13] E. coli Tuner (DH3)pLysS cells to give $E$. coli Tuner ( $\left.\mathrm{pET} 32 \mathrm{a}-x y n A_{M G 1}\right)$ expression strain. Positive clones were proven by colony PCR and the presence of xylanase activity in the cell lysate. Selected E. coli Tuner (pET32a-xynA $A_{M G 1}$ ) clone was grown in LB broth containing $34 \mu \mathrm{g} / \mathrm{mL}$ and $100 \mu \mathrm{g} / \mathrm{mL}$ of chloramphenicol and ampicillin, respectively, incubated at $37^{\circ} \mathrm{C}$ with $200 \mathrm{rpm}$ shaking until the culture reached an $\mathrm{OD}_{600} \mathrm{~nm}$ of 0.6 . Then the $x y n A_{M G 1}$ gene expression was induced by adding IPTG to a final concentration of $0.4 \mathrm{mM}$ and the culture was further incubated for $5 \mathrm{~h}$ at $37^{\circ} \mathrm{C}$ with $200 \mathrm{rpm}$ shaking. The cells were harvested by centrifugation, resuspended in nine volumes of ice-cold phosphate buffer (50 mM sodium phosphate, $1.2 \mathrm{M}$ $\mathrm{NaCl}, 10 \mathrm{mM}$ imidazole) $\mathrm{pH}$ 7.2, and subjected to ultrasonic cell disruption while keeping in an ice-bath. Unbroken cells and insoluble cell debris were removed by centrifugation at $12,000 \mathrm{~g}$ for $25 \mathrm{~min}$ yielding the clear soluble cell lysate. The cell lysates were subjected to sodium dodecyl sulphate polyacrylamide gel electrophoresis (SDS-PAGE, $12 \%$ separating gel) to determine the expression profile of the $\mathrm{Xyn}_{\mathrm{MG}}$ xylanase. The recombinant $\mathrm{XynA}_{\mathrm{MG} 1}$ was purified from cell lysate by Immobilized Metal Affinity Chromatography (IMAC) using the TALON Metal Affinity Resin (Clontech Lab, Inc.) charged with cobalt. The IMAC column (Tricon $10 \times 100 \mathrm{~mm}$ ) was operated using an ÄKTA purifier FPLC system (GE Healthcare Bio-Sciences) at the $0.2 \mathrm{~mL} / \mathrm{min}$ flow rate. The bound proteins were eluted with 10 bed volumes of linear gradient of $1-150 \mathrm{mM}$ imidazole in phosphate buffer ( $50 \mathrm{mM}$ sodium phosphate, $1.2 \mathrm{M} \mathrm{NaCl}$ ) pH 7.2, at $0.5 \mathrm{~mL} / \mathrm{min}$ flow rate. Fractions containing xylanase activity were pooled and concentrated by the Amicon ${ }^{\circledR} 30 \mathrm{kDa}$ cut off centrifugal filter device (EMD Millipore) at 4,000 rpm, $4^{\circ} \mathrm{C}$. The concentrated $\mathrm{XynA}_{\mathrm{MG}}$ was repurified using the IMAC and then desalted as described above. The pET-32a derived Trx-His॰tag which fused to the N-terminus of the expressed $\mathrm{XynA}_{\mathrm{MG} 1}$ was removed by digestion with enterokinase (New England BioLabs) for $16 \mathrm{~h}$ at $23^{\circ} \mathrm{C}$. The digestion mixture was then loaded onto the IMAC column as above, and the 
recombinant $X y n A_{M G 1}$ was retrieved from the flow-through, while the Trx-His•tag and the uncleaved Trx-His-Xyn $A_{M G 1}$ remained bound to the TALON resin. Protein concentration was determined by the Bradford method using bovine serum albumin (BSA) as the standard. The purity of $\mathrm{XynA}_{\mathrm{MG} 1}$ was analyzed on SDS-PAGE. The zymogram analysis was done on $12 \%$ gel native PAGE containing $0.2 \%$ oat-spelt xylan as the substrate [14].

\subsection{Biochemical Characterization of Purified Xyn $A_{M G 1}$} Xylanase. Substrate specificity of $\mathrm{XynA}_{\mathrm{MG} 1}$ was determined by assaying activity towards different substrates at $1 \%(\mathrm{w} / \mathrm{v})$ concentration in $50 \mathrm{mM}$ citrate buffer $\mathrm{pH}$ 5.5. The tested substrates were of the following polymers: beechwood xylan, oat-spelt xylan, $\alpha$-cellulose, carboxymethyl cellulose, starch, and barley $\beta$-glucan $[14,15]$. The xylanase activity was estimated by measuring reducing sugar released from the reaction using the DNS method [16]. Xyn $\mathrm{A}_{\mathrm{MG} 1}$ was also tested against $4 \mathrm{mg} / \mathrm{mL}$ of 4 -nitrophenyl- $\beta$-D-xylopyranoside, 4-nitrophenyl- $\beta$-D-cellobioside, and 4-nitrophenyl$\alpha$-D-galactopyranoside synthetic chromogenic substrates as previously described [17]. End products from $\mathrm{XynA}_{\mathrm{MG}}$ catalyzed hydrolysis of beechwood xylan and 4-nitrophenyl$\beta$-D-xylopyranoside were analyzed by thin-layer chromatography (TLC) on a Silica gel $60 \mathrm{~F}_{254}$ plate $(10 \times 10 \mathrm{~cm})$ (Merck, Darmstadt, Germany) using a developing solvent (chloroform/acetic acid/water 6:7:1, v/v). The products were visualized by spraying with ethanol/sulfuric acid $(95: 5$, $\mathrm{v} / \mathrm{v}$ ) and heating for $10 \mathrm{~min}$ at $100^{\circ} \mathrm{C}$ as previously described [18].

2.5. Effect of $p H$ and Temperature on $X y n A_{M G 1}$ Activity and Stability. To determine the optimum $\mathrm{pH}$ for $\mathrm{XynA}_{\mathrm{MG} 1}$ activity, the enzyme was allowed to function in buffers ranging from $\mathrm{pH} 3.0$ to 11.0 with $1 \mathrm{pH}$ unit interval. The buffers used were $50 \mathrm{mM}$ citrate buffer for $\mathrm{pH}$ range of 3-6, $50 \mathrm{mM}$ sodium phosphate buffer for $\mathrm{pH}$ range of $6-8$, and $50 \mathrm{mM}$ glycine $\mathrm{NaOH}$ buffer for $\mathrm{pH}$ range of $8-11$. $\mathrm{XynA}_{\mathrm{MG}}$ activities were determined using the standard enzyme assay, and a $\mathrm{pH}$ versus enzyme activity profile was plotted [19]. The enzyme stability at different $\mathrm{pH}$ was determined by preincubating Xyn $\mathrm{A}_{\mathrm{MG} 1}$ in different buffers from $\mathrm{pH} 3.0$ to 11.0 (with $1 \mathrm{pH}$ unit interval) for $30 \mathrm{~min}$ and $60 \mathrm{~min}$ at $25^{\circ} \mathrm{C}$. Then, the remaining activities of the enzyme were measured under standard condition [20].

The optimum temperature for xylanase activity was determined by assaying the enzyme activity at different temperatures from 20 to $100^{\circ} \mathrm{C}$ with step increment of $5^{\circ} \mathrm{C}$. Thermal stability was determined by incubating the enzyme in $\mathrm{pH} 5.5$ buffer in the absence of substrate at the temperature range of 45 to $70^{\circ} \mathrm{C}$. Then, the residual activities were measured under standard conditions [21].

2.6. Effect of Metal Ions, Salt, Chemical Agents, and Solvents on $X y n A_{M G 1}$ Activity. XynA $\mathrm{XG1}_{\mathrm{MG}}$ was incubated with $2 \mathrm{mM}$ and $10 \mathrm{mM}$ solution of $\mathrm{Mn}^{2+}, \mathrm{Ca}^{2+}, \mathrm{Zn}^{2+}, \mathrm{Co}^{2+}, \mathrm{Cu}^{2+}, \mathrm{Mg}^{2+}$, or nonmetal reagents including ethylenediaminetetraacetic acid (EDTA), dithiothreitol (DTT), $\beta$-mercaptoethanol $(\beta \mathrm{ME})$, and detergents Triton X-100, Tween 80, and SDS, for $1 \mathrm{~h}$ at room temperature. Residual activity was measured under standard condition [22].

To investigate the impact of sodium chloride on $\mathrm{Xyn}_{\mathrm{MG}}$ activity, the purified $\mathrm{XynA}_{\mathrm{MG}}$ was incubated with 0-4 M $\mathrm{NaCl}$ for 0 and $2 \mathrm{~h}$ and then assayed under standard conditions in the reaction containing $\mathrm{NaCl}$ at the same concentration as previously incubated [23].

$\mathrm{XynA}_{\mathrm{MG1}}$ was incubated in aqueous solution of different solvents (acetone, methanol, ethanol, and propanol) at different concentrations (0-5 M) for $30 \mathrm{~min}$. Residual activity was determined by using assay system under optimal conditions [22].

The nucleotide sequence of the $x y n A_{M G 1}$ gene reported in this paper has been deposited in the GenBank database with an accession number of KX347434.

\section{Results and Discussion}

3.1. In Silico Sequence and Structural Analyses of Xyn $A_{M G 1}$ Xylanase. An E. coli clone harboring DNA from chicken cecum metagenome was found to contain an open reading frame of $1,116 \mathrm{bp}$ encoding a protein of 372 amino acids, sequence of which was related to xylanase family GH10 and it was named the $\mathrm{XynA}_{\mathrm{MG}}$ xylanase. The first $23 \mathrm{~N}$-terminus amino acids were predicted to be the signal peptide which guides secretion of the 349 amino acids' mature enzyme having a molecular mass and a pI value of 40,013 Da and 5.76, respectively.

Multiple sequence alignment of the $\mathrm{XynA}_{\mathrm{MG}}$ protein (including the signal peptide) with similar proteins, BLASTed and retrieved from the GenBank, revealed the highest identity at $59 \%$ to those of endo-1,4-beta-xylanases from Prevotella bryantii and Prevotella ruminicola and 58\% identity to that from Prevotella copri. XynA $\mathrm{MG}_{\mathrm{MG}}$ has two conserved motifs, DVVNE and TEXD, of the GH10 family xylanase which contained the two glutamate residues (E157 and E 262) predicted to be the catalytic sites, and an invariant asparagine (N156) preceding the glutamate in the first motif serving as an acid/base catalyst (Figure 1) [24-26].

Phylogenetic analysis of $\mathrm{Xyn}_{\mathrm{MG}}$ placed it in the cluster within Prevotella xylanases clade with high bootstrap value support (Figure 2). Among these, the highest amino acid sequence identity was only $59 \%$ which was the xylanase from Prevotella bryantii and Prevotella ruminicola. This indicated that $\mathrm{XynA}_{\mathrm{MG}}$ is a distinctly new endo-1,4 $\beta$-xylanase member of the family GH10, probably from a bacterium in the genus Prevotella.

Structure of Xyn $\mathrm{A}_{\mathrm{MG}}$ was modeled [27] using the protein crystal structure 2 cnc.1.A of a closely related thermostable GH10 xylanase from Cellvibrio mixtus as a template. The amino acid sequence stretches in the $\mathrm{XynA}_{\mathrm{MG} 1}$ molecule predicted to form different secondary structures (alphahelices, beta-sheet, and loops) are shown in Figure 3(a). Despite the low degrees of amino acid sequence homology of the mature forms of the two enzymes (40.2\% identity; $58.6 \%$ similarity), the secondary structure profiles at corresponding positions along the amino acid sequences of the two xylanases are highly similar (Figure 3(a)). Three-dimensional structure 


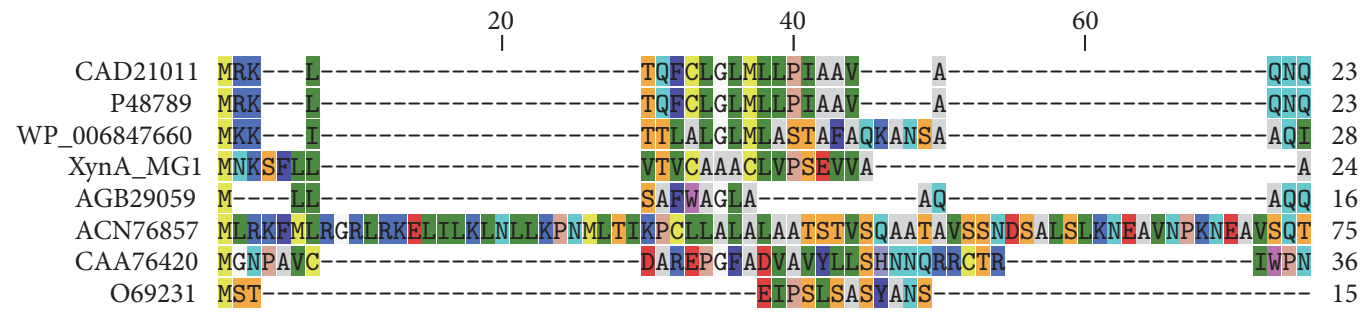

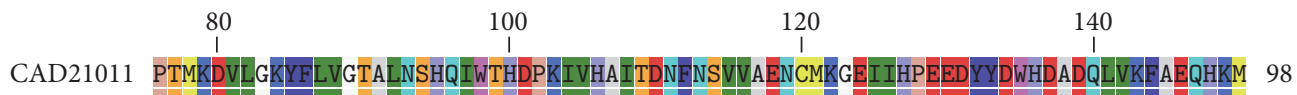

P48789 PTMKDVLGKYFLVGTALNSHQIWTHDPKIVHAITDNFNSVVAENCMKGEI I HPEEDYYDWHDADQLVKF AEQHKM 98

WP_006847660 PTFQETMGKYFLVGAAINTDLPNGQDPAGEEVVKKQFNQVVAENCMKGEKNHPEVNRFDFTDGDKLADWAEKNGK 103

XYnA_MG1 DTLKDVLGKKYTTVGAVNVDVVWGRNAAEAKIVTDNFNSIVAENCMKGEEIHPEEDTYEWDDADRTVKFAEDNGL 99

AGB29059 PGLKDALGPYFQVGVALNTRITAGGDAQADALVDRHFNTIVAENCFKGGEVTPREGVYDFTDADAVVSYAEKHGL 91

ACN76857 KSLKAHFSKQFLVGSAINAQQAKRTEQDTDALIITQFNTITPENELKWERIHPKPDAYD SLSDEYVHYGLANNM 150

CAA76420 SIWWEVFKDDFDIGAAVTSRTV----DSAADLLRAQYNSITAENEMNPINTQPSEGVFTFEQADKIADFAAKHGK 107

O69231 -

\begin{tabular}{ccccc}
160 & 180 & 200 & \multicolumn{2}{c}{20} \\
CAD21011 & TVHGHCLVWHSQAPKWMFTDKEGKEVTREVLIDRMYHHITNVVKRYKGKIKGWWVVNEAILDNGE--YKQSPYYK & 171
\end{tabular}

P48789 TVHGHCLVWHSQAPKWMFTDKEGKEVTREVLIDRMYHHITNVVKRYKGKIKGWDVVNEAILDNGE--YRQSPYYK 171

WP_006847660 TLIGHCLVWHSQPPKWMFTDDKGNLVSREVLIGRMYNHIMNVVTHYKGRVKGWWVVNEAFEDDGS--YRKSLYYK 176

XYnA_MG1 EMIGHCLVWHSQPPKWMFTDEKGDTVSREVLIRRMRDHITTVMTRYKGRIKGWDVVNEAVNDDGT--MRETPYYK 172

AGB29059 RLIGHCLVWHSQAPDWEFKHADGTVVSRDELIRRMQTHIRTMVGRYKGKVYGW VVVNEAVEDNGE--ERRSPYYN 164

ACN76857 FIIGHTLVWHSQTPDWVFENAQGELLTREALLARMKEHIHTVVSRYKGKIKGW VVVNEALNEDGS--LRDSKWRQ 223

CAA76420 KLRGHTLVWHNQTPDWFFEAPGGGPAGKETLLRRMRDHIHAVAGRYKGRTYCW VVNEAVADEGEQWLRASKWHD 182 O69231 GVRGHTLVWHNQTPAWMFEDASGGTASREMMLSRLKQHIDTVVGRYKDQIYAW VVVNEAIEDKTDLIMRDTKWLR 151

$\begin{array}{cccc}240 & 260 & 280 & 300 \\ \text { CAD21011 IIGPDFIKLAFIFAHQADPDAELYYNDYSMSIPAKRNAVVKLVKELKAAGCRIDAVGMQSHNGFNYPNLEDYENS } & 246\end{array}$ P48789 IIGPDFIKLAEIFAHQADPDAELYYNDYSMSIPAKRNAVVKLVKELKAAGCRIDAVGMQSHNGENYPNLEDYENS 246

WP 006847660 IIGPEFIELAFRFAHEADPNVELYYNDYSTSKPAKREAICKLVRDLKAKGLRIDAVGMQSHNG FDYPDYAEYEKS 251

XYnA_MG1 IIGPDYIELAFKFAHAADPDAEL Y INDY AMAKPGKRATTCRIVRDLKAKGCRVDAIGMQSHNGYDYPDLKEYEAS 247

AGB29059 IIGPEFIDIAFRTAHEADPDAEL YYNDYSMAKPGKRTAVCRLVRHLQSEGLRIDAVGMQSHQGLDYPDLADYEAS 239

ACN76857 IIGDDFIEKA FTYAHAADPDAKL YYNDYNLYKPEKSAGAAKLIKSLQDKGIPVHGVGLQGHYSLTHPALNELDDA 298

CAA76420 MVGPEFIVRAFEYAHEADPDALLF YND YNECNPAKRDKIIRLVKWLKEQGAPIHGIGMQGHYNLASPSIAEVREA 257 O69231 LLGEDYLVQAENMAHEADPNALLFYNDYNETDPVKREKIYNLVRSLLDQGAPVHGIGMQGHWNIHGPSMDEIRQA 226

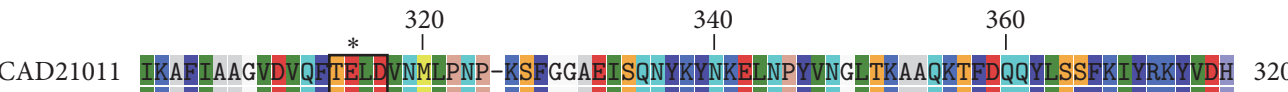

P48789 IKAFIAAGVDVQFTELDVNMLPNP-KSSFGGAEISQNYKYNKELNPYVNGLTKAAQKTEDQQYLSEFKIYRKYVDH 320

WP_006847660 IEAEAGEGVKVMLTELDMNMLPNP-EGEGGAEISQRFELQKKYNPYYVKGLDKKAQKL FNQRYLDLFKIVERHKDV 325

XYnA_MG1 IDSEAACGVKVMMMTELDLNMLPNP-ESFSGAEISQNEKYDEKYNPYKNGLTPEAERLFEQRYLEMFKIYYYRHRHQ 321

AGB29059 IDSFAACGVKVSLSELDLNVLPSP-RNFGGAGIEQNYAFQQPMNP YDDGVADVQRQIDARWMDFFRIYRRHASQ 313

ACN76857 LTLFASLGIESMITELDVSVLPFPSEAIQGADISQDLALNKALNPYPDGLPEAQQDALTARYKEIFSVFLTHQDT 373

CAA76420 IEKYAELGLVIHVTELDMSV---------------YAWDDRRTDLLEPTAEMVERQ-AELYEQLESLYREYRDV 315

O69231 IERYASLDVQLHVTELDLSV---------------FRHEDQRTDLTEPTAEMAELQ-QKRYEDIFGLFREYRSN 284

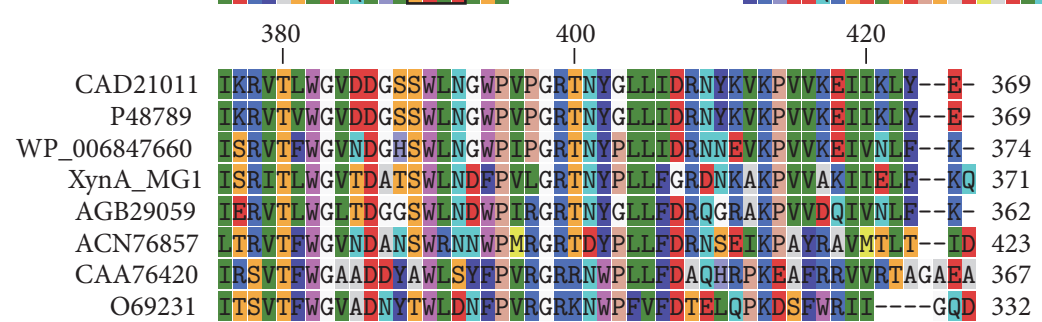

FIGURE 1: Amino acid sequence alignment of $\mathrm{XynA}_{\mathrm{MG} 1}$ with closely related GH10 family beta-xylanases from Prevotella bryantii B14 (CAD21011), Prevotella ruminicola B(1)4 (P48789), Prevotella copri DSM 18205 (WP_006847660), Prevotella dentalis DSM 3688 (AGB29059), Paraglaciecola mesophila KMM 241 (ACN76857), Thermobacillus xylanilyticus D3 (CAA76420), and Paenibacillus barcinonensis BP-23 (O69231). The highly conserved motifs DVVNE and TEXD are shown in boxes, each containing an active site glutamate (marked with an asterisk) and an invariant asparagine residue (marked with an arrow) preceding the active site glutamate in the first box. 


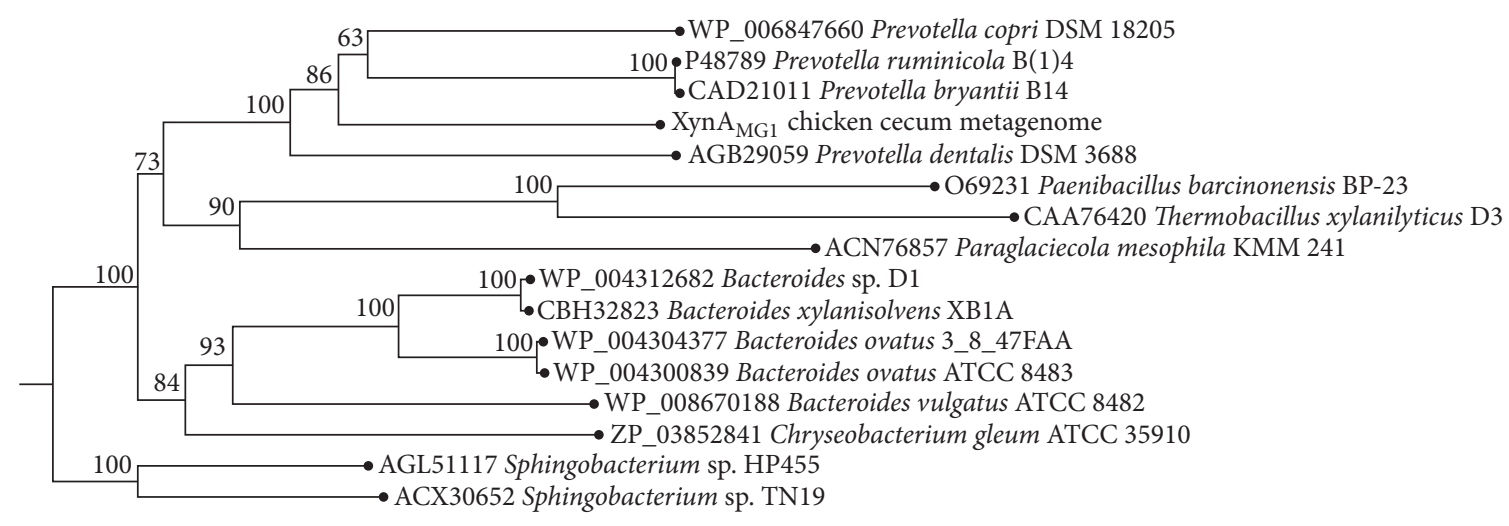

0.400

FIGURE 2: Phylogenetic analysis based on the amino acid sequence of $\mathrm{XynA}_{\mathrm{MG} 1}$ and related GH10 family xylanases. The phylogenetic tree was constructed using the neighbor joining method (CLC Main Workbench version 7.7). The lengths of the branches indicate the relative divergence among amino acid sequences. The percentage bootstrap values based on 1,000 bootstrap replications are shown at the nodes. Xylanases of Sphingobacterium sp. TN19 and Sphingobacterium sp. HP455 are used as outgroups. Accession numbers of the xylanase amino acid sequences are shown with the names of the host organisms. The scale bar represents the number of changes per amino acid position.

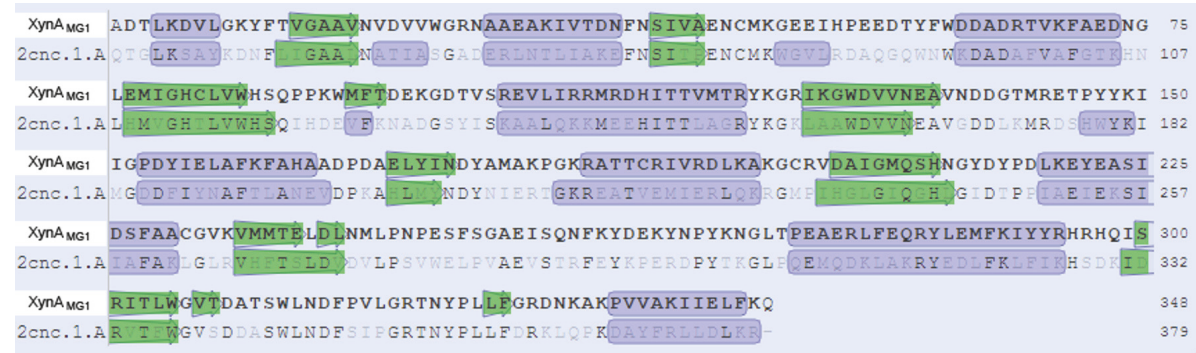

(a)

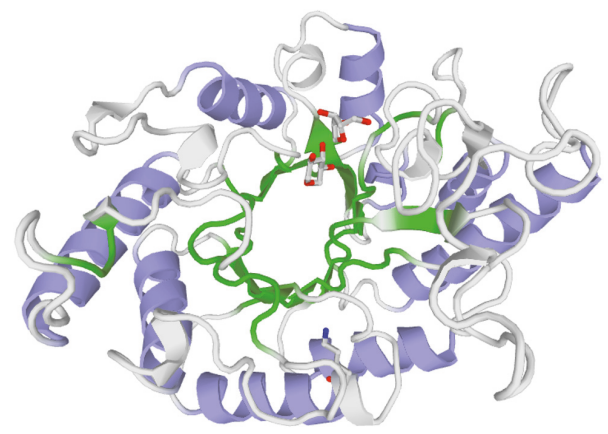

(b)

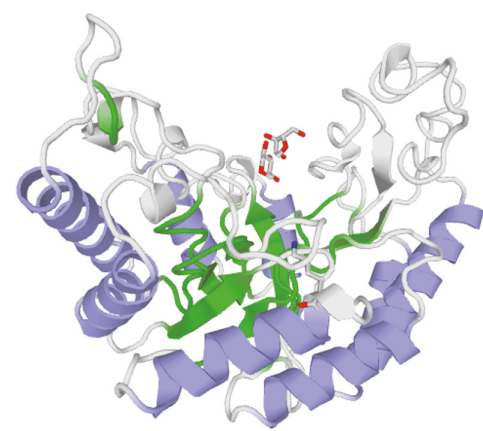

(c)

FIGURE 3: Structure of $\mathrm{XynA}_{\mathrm{MG}}$ modeled using crystal structure of a closely related GH10 endo-xylanase (2cnc.1.A) as a template. (a) Predicted secondary structure of $\mathrm{XynA}_{\mathrm{MG}}$; purple box: alpha-helix; green arrow: beta-sheet. (b, c) Three-dimensional representation of Xyn $\mathrm{A}_{\mathrm{MG} 1}$ with alpha-helices, beta-sheets, and loops folded into the typical $(\beta / \alpha)_{8}$ TIM-barrel structure; (b) top view; (c) side view. The Xyn $\mathrm{A}_{\mathrm{MG} 1} \mathrm{xylanase}$ is shown with 2 molecules of $\beta$-D-xylopyranose (stick models) on the catalytic face.

modeling of $\mathrm{XynA}_{\mathrm{MG1}}$ revealed the typical $(\beta / \alpha)_{8}$ TIM-barrel fold resembling the shape of a salad bowl (Figures 3(b) and $3(\mathrm{c}))$ which is similar to other known GH10 family xylanases [24].

3.2. Cloning, Expression, and Purification of $X y n A_{M G 1}$ Xylanase. Xyn $\mathrm{A}_{\mathrm{MG} 1}$ without the signal peptide was expressed in E. coli with thioredoxin A peptide and hexa-histidine tags fused to its $\mathrm{N}$-terminus to enhance soluble protein folding and facilitate protein purification, respectively. The purified fusion protein was digested with enterokinase to remove the peptide tags and subjected to second round of purification to yield the purified mature $\mathrm{XynA}_{\mathrm{MG} 1}$ enzyme for characterization experiments. The Trx-His-XynA $\mathrm{MG}_{\mathrm{M} 1}$ fusion enzyme was catalytically active; however, its activity was around half of that of the mature $\mathrm{XynA}_{\mathrm{MG} 1}$ (data not 


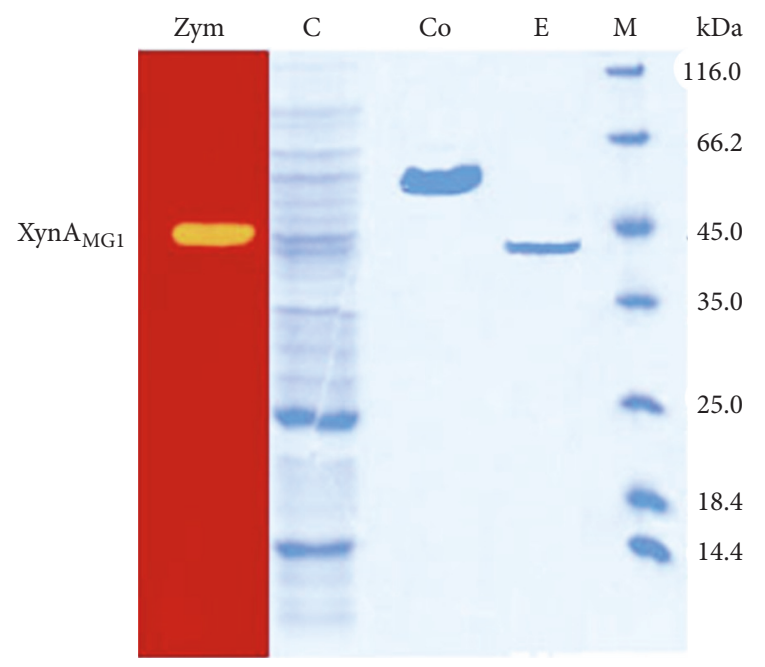

FIgURe 4: Purification steps of $\mathrm{Xyn}_{\mathrm{MG1}}$ and zymogram analysis. Proteins were separated with $12 \%$ gel SDS-PAGE. Lane (Zym) zymogram, lane (C): total soluble cell lysate from $E$. coli host expressing $\mathrm{XynA}_{\mathrm{MG} 1}$, lane (Co): Trx-His-XynA $\mathrm{A}_{\mathrm{MG}}$ fusion protein purified by TALON cobalt resin, lane (E): purified $\mathrm{XynA}_{\mathrm{MG} 1}$ after digestion with enterokinase, and lane $(\mathrm{M})$ : protein molecular weight markers.

shown). Figure 4 shows the SDS-PAGE analysis of different forms of the enzyme through successive purification steps. The molecular mass of the purified $\mathrm{XynA}_{\mathrm{MG} 1}$ after removal of the tags was determined to be around $41.0 \mathrm{kDa}$ which was close to the theoretical value of $40.013 \mathrm{kDa}$ calculated based on the amino acid sequence. Xylanase zymogram analysis displayed a clear band of xylan digestion corresponding with the position of the XynA $\mathrm{MG}_{\mathrm{MG}}$ protein band (Figure 4).

3.3. Substrate Specificity. The purified $\mathrm{XynA}_{\mathrm{MG1}}$ was found to exert its highest hydrolytic activity towards the beechwood xylan while the activity towards oat-spelt xylan was $94 \%$ relative to that of the beechwood xylan. No activity could be measured with $\alpha$-cellulose, carboxymethyl cellulose, starch, and $\beta$-glucan as substrates. Upon testing with synthetic chromogenic substrates, $\mathrm{XynA}_{\mathrm{MG1}}$ could hydrolyze only the 4nitrophenyl- $\beta$-D-xylopyranoside while 4 -nitrophenyl- $\beta$-Dcellobioside or 4-nitrophenyl- $\alpha$-D-galactopyranoside could not serve as substrates (Table 1). The relatively specific xylanase property of $\mathrm{XynA}_{\mathrm{MG} 1}$ is in contrast with most xylanases of family 10 which have both xylanase and cellulase activities. However, a number of xylanases of family 10 showed only xylanase activity such as xylanase Xyn10N18 derived from a bovine rumen metagenomic library [28] and Xyn10J from a compost metagenomic library which showed negligible hydrolytic activity against carboxymethyl cellulose [18]. Added to the latter group is $\mathrm{XynA}_{\mathrm{MG} 1}$ isolated in this study and the possession of the cellulase-free xylanase activity makes it potentially very useful for biobleaching of pulps [18].

TLC analysis of the reaction mixture of $\mathrm{XynA}_{\mathrm{MG} 1}$ catalyzed hydrolysis of beechwood xylan, compared with the results reported for the novel family 10 xylanase Xyn10J from a compost metagenomic library [18], suggested that xylobiose
TABLE 1: Substrate specificity of the purified recombinant $\mathrm{XynA}_{\mathrm{MG} 1}$

\begin{tabular}{lc}
\hline Substrate $^{\mathrm{a}}$ & Relative activity $(\%)^{\mathrm{b}}$ \\
\hline Beechwood xylan & 100 \\
Oat-spelt xylan & 94 \\
Carboxymethyl cellulose & 0 \\
$\alpha$-Cellulose & 0 \\
Starch & 0 \\
Barley $\beta$-glucan & 0 \\
4-nitrophenyl- $\beta$-D-xylopyranoside & 55 \\
4-nitrophenyl- $\beta$-D-cellobioside & 0 \\
4-nitrophenyl- $\alpha$-D-galactopyranoside & 0 \\
${ }^{\mathrm{a}}$ The test concentration for polysaccharide substrates was $1 \%(\mathrm{w} / \mathrm{v})$ while that \\
for the synthetic chromogenic substrates was $4 \mathrm{mg} / \mathrm{mL}{ }^{\mathrm{b}}$ The activity towards \\
beechwood xylan which was the highest activity was defined as 100\%. All the \\
values are means of three replications.
\end{tabular}

$\left(\mathrm{X}_{2}\right)$ and xylotetraose $\left(\mathrm{X}_{4}\right)$ were two major end products, and xylose $\left(X_{1}\right)$ was produced as a minor product (Figure $5(\mathrm{a})$ ). $\mathrm{XynA}_{\mathrm{MG1}}$ showed high hydrolytic activity on 4-nitrophenyl$\beta$-D-xylopyranoside ( $\mathrm{pNP}-\mathrm{X}$ ), a synthetic chromogenic substrate, releasing equimolar of two products 4-nitrophenol and xylose. The extent of the reaction is determined by adding $1 \mathrm{~mL}$ of $1 \mathrm{M} \mathrm{Na}_{2} \mathrm{CO}_{3}$ to stop the reaction and turn the 4nitrophenol to yellow color which was quantified by measuring the absorbance at $400 \mathrm{~nm}$ [17]. The present xylose as a reaction product was shown by TLC (Figure 5(b)). XynA $\mathrm{MG}_{\mathrm{MG}}$ effectively digested the synthetic substrate 4-nitrophenyl- $\beta$ D-xylopyranoside releasing large amount of xylose. However, upon digestion of beechwood xylan, a natural substrate, the major end product was not xylose $\left(\mathrm{X}_{1}\right)$ but the xylotetraose $\left(\mathrm{X}_{4}\right)$ and xylobiose $\left(\mathrm{X}_{2}\right)$ suggested that $\mathrm{Xyn}_{\mathrm{MG}}$ could catalyze transglycosylation reactions. Xylanases with transglycosylation activity have been previously reported in the GH10 family, such as Xyn10J from compost metagenome and XynB from Thermotoga maritima and several GH11 xylanases such as Xyn1 from Paenibacillus sp. W-61, TfxA from Thermomonospora fusca, AnxA from Aspergillus niger, and XynA from Paecilomyces thermophila [18]. With the transglycosylation activity, $\mathrm{XynA}_{\mathrm{MG} 1}$ can be useful in the application for the synthesis of alkyl oligoglycosides [18].

\subsection{Effects of $p H$ and Temperature on Enzyme Activity and} Stability. The purified $\mathrm{XynA}_{\mathrm{MG} 1}$ showed the typical bellshaped $\mathrm{pH}$ profile with an optimal $\mathrm{pH}$ of 6 . It retained $32 \%$ of its initial activity at $\mathrm{pH} 9$ and completely lost all of its activity at $\mathrm{pH} 10$ (Figure 6(a)). This is consistent with xylanases previously reported $[26,29]$ and with the physiological function of xylanases in the cecum of broiler chickens since the $\mathrm{pH}$ values in cecum broiler chicken are generally 5.5-6 [30]. The xylanase $\mathrm{XynA}_{\mathrm{MG} 1}$ enzyme was stable between $\mathrm{pH} 5.0$ and 8.0 for $60 \mathrm{~min}$, retaining around $70 \%$ of its activity at $\mathrm{pH} 8.0$ (Figure 6(b)). It was fairly stable at high $\mathrm{pH}$ similar to other bacterial xylanases $[26,31]$.

The optimal temperature of $\mathrm{XynA}_{\mathrm{MG} 1}$ was $45^{\circ} \mathrm{C}$ (Figure $6(\mathrm{c})$ ), which was close to those found in other metagenomic family 10 xylanases $[26,29]$. Most xylanases of family 


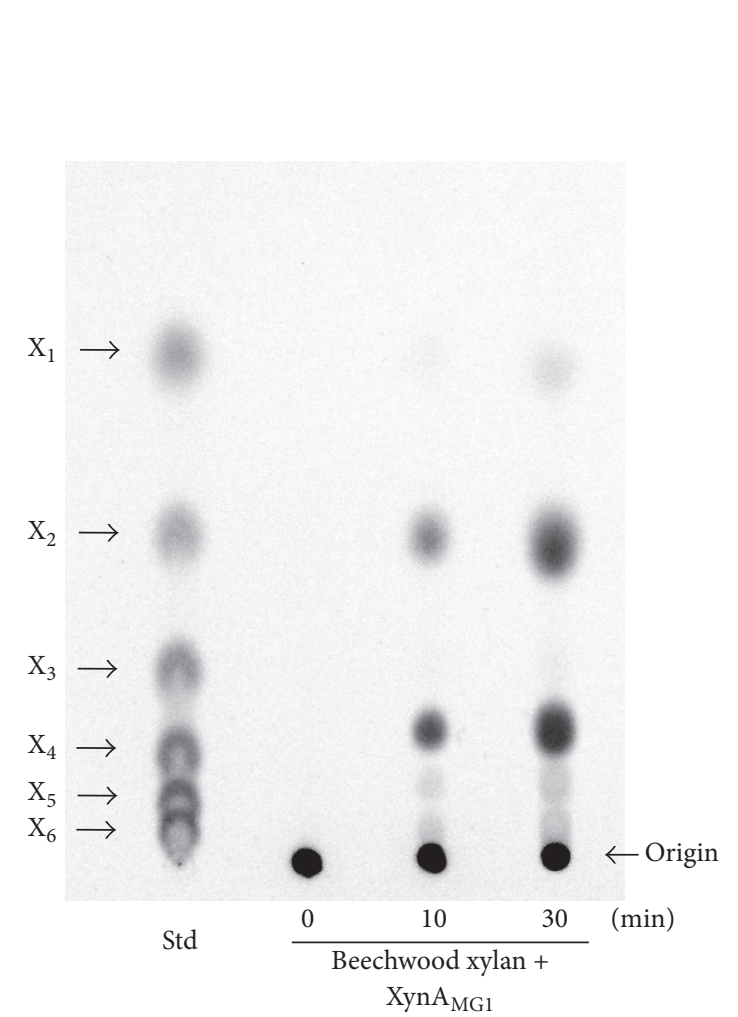

(a)

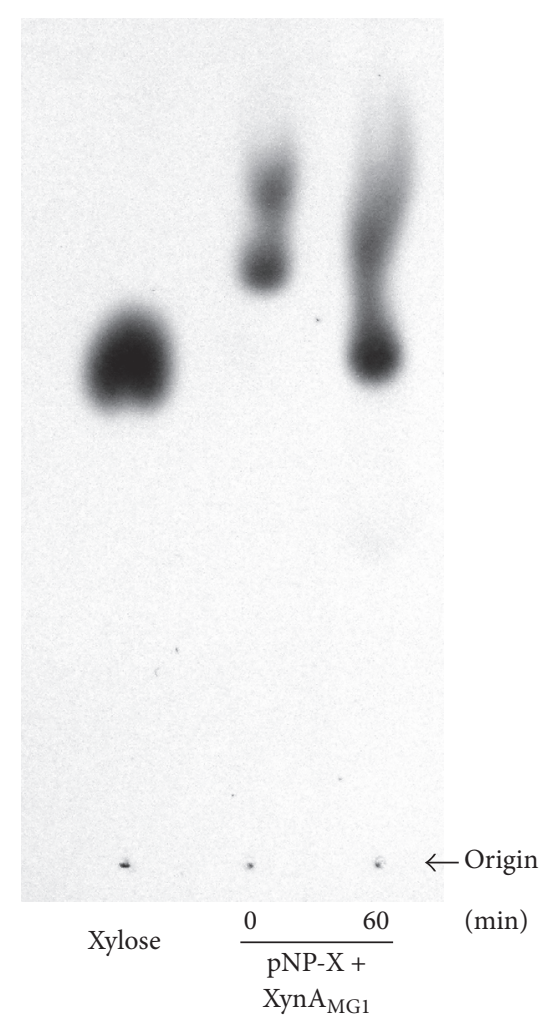

(b)

FIGURE 5: Thin-layer chromatography analysis of end products of Xyn $\mathrm{A}_{\mathrm{MG} 1}$ catalyzed hydrolysis of beechwood xylan (a) and 4-nitrophenyl$\beta$-D-xylopyranoside (b). $\mathrm{X}_{1}$, xylose; $\mathrm{X}_{2}$, xylobiose; $\mathrm{X}_{3}$, xylotriose; $\mathrm{X}_{4}$, xylotetraose; $\mathrm{X}_{5}$, xylopentaose; $\mathrm{X}_{6}$, xylohexaose; Std, molecular weight standard mix of $\mathrm{X}_{1}$ to $\mathrm{X}_{6}$; $\mathrm{pNP}-\mathrm{X}$, 4-nitrophenyl- $\beta$-D-xylopyranoside.

10 were known to have optimum temperature of $40-80^{\circ} \mathrm{C}$ [32]. $\mathrm{XynA}_{\mathrm{MG1}}$ retained $72 \%$ of its activity after incubating at $60^{\circ} \mathrm{C}$ for $45 \mathrm{~min}$ (Figure $6(\mathrm{~d})$ ). However, when the temperature was $70^{\circ} \mathrm{C}$, the enzyme completely lost the activity. Interestingly, it had around $30 \%$ activity even at $100^{\circ} \mathrm{C}$ in the presence of the substrate (Figure 6(c)). Many enzymes were known to be more stable in the presence of their substrates $[33,34]$.

3.5. Effect of Metal Ions and Chemicals on the Xyn ${ }_{M G 1}$ Activity. As shown in Table 2, the $\mathrm{XynA}_{\mathrm{MG} 1}$ activity was slightly deactivated by metal ions $\mathrm{Co}^{2+}, \mathrm{Zn}^{2+}, \mathrm{Mn}^{2+}$, and $\mathrm{Mg}^{2+}$ at $2 \mathrm{mM}$ and $10 \mathrm{mM}$ in a concentration-dependent manner. Moderate inhibitions were found with $\mathrm{Ca}^{2+}$ and strong inhibitions were found with $\mathrm{Cu}^{2+}$. The inhibitions of xylanase activity by $\mathrm{Cu}^{2+}$ ion were commonly reported $[35,36]$.

Reducing agents such as $\beta$-mercaptoethanol and DTT slightly affected the $\mathrm{XynA}_{\mathrm{MG1}}$ activity suggesting that xylanase does not seem to need disulfide bonds to achieve the hydrolysis reaction [37].

$\mathrm{XynA}_{\mathrm{MG} 1}$ enzyme retained more than $87 \%$ of its activity after incubation for $60 \mathrm{~min}$ with $10 \mathrm{mM}$ of EDTA. The resistance of $\mathrm{Xyn}_{\mathrm{MG}}$ to the chelating reagent suggested that it is not a metalloenzyme and no metal ion is essential for $\mathrm{XynA}_{\mathrm{MG} 1}$ activity. Its stability against the chelating agent, one of the indispensable ingredient in detergent formulations, is
TABLE 2: Effect of metal ions, reducing agents, and ionic and nonionic surfactants on $\mathrm{XynA}_{\mathrm{MG1}}$ xylanase activity.

\begin{tabular}{lcc}
\hline Agent & $2 \mathrm{mM}$ & $10 \mathrm{mM}$ \\
\hline None & $100 \pm 0.2$ & $100 \pm 0.2$ \\
$\mathrm{Mg}^{2+}$ & $96.8 \pm 0.9$ & $92.4 \pm 0.7$ \\
$\mathrm{Ca}^{2+}$ & $91.4 \pm 3.1$ & $77.3 \pm 2.9$ \\
$\mathrm{Mn}^{2+}$ & $99.9 \pm 2.5$ & $97.3 \pm 3.7$ \\
$\mathrm{Co}^{2+}$ & $98.5 \pm 2.9$ & $94.2 \pm 2.2$ \\
$\mathrm{Cu}^{2+}$ & $86.3 \pm 2.2$ & $41.4 \pm 1.9$ \\
$\mathrm{Zn}^{2+}$ & $98.8 \pm 0.9$ & $95.5 \pm 1.4$ \\
$\beta$-Mercaptoethanol & $95.3 \pm 1.0$ & $93.6 \pm 1.1$ \\
DTT & $95.0 \pm 1.6$ & $94.7 \pm 2.0$ \\
EDTA & $91.6 \pm 3.1$ & $87.3 \pm 3.1$ \\
SDS & $22.1 \pm 1.5$ & $14.7 \pm 1.3$ \\
Triton X-100 & $96.2 \pm 2.2$ & $103.9 \pm 1.2$ \\
Tween- 80 & $97.9 \pm 2.8$ & $108.8 \pm 2.6$ \\
\hline
\end{tabular}

The purified $\mathrm{Xyn}_{\mathrm{MG} 1}$ was assayed in the standard assay condition in the presence of $2 \mathrm{mM}$ or $10 \mathrm{mM}$ test agents. The xylanase activity measured in the absence of the test agent was set as $100 \%$. All the values are means of three replications.

of great importance and worth further investigation on its application. 

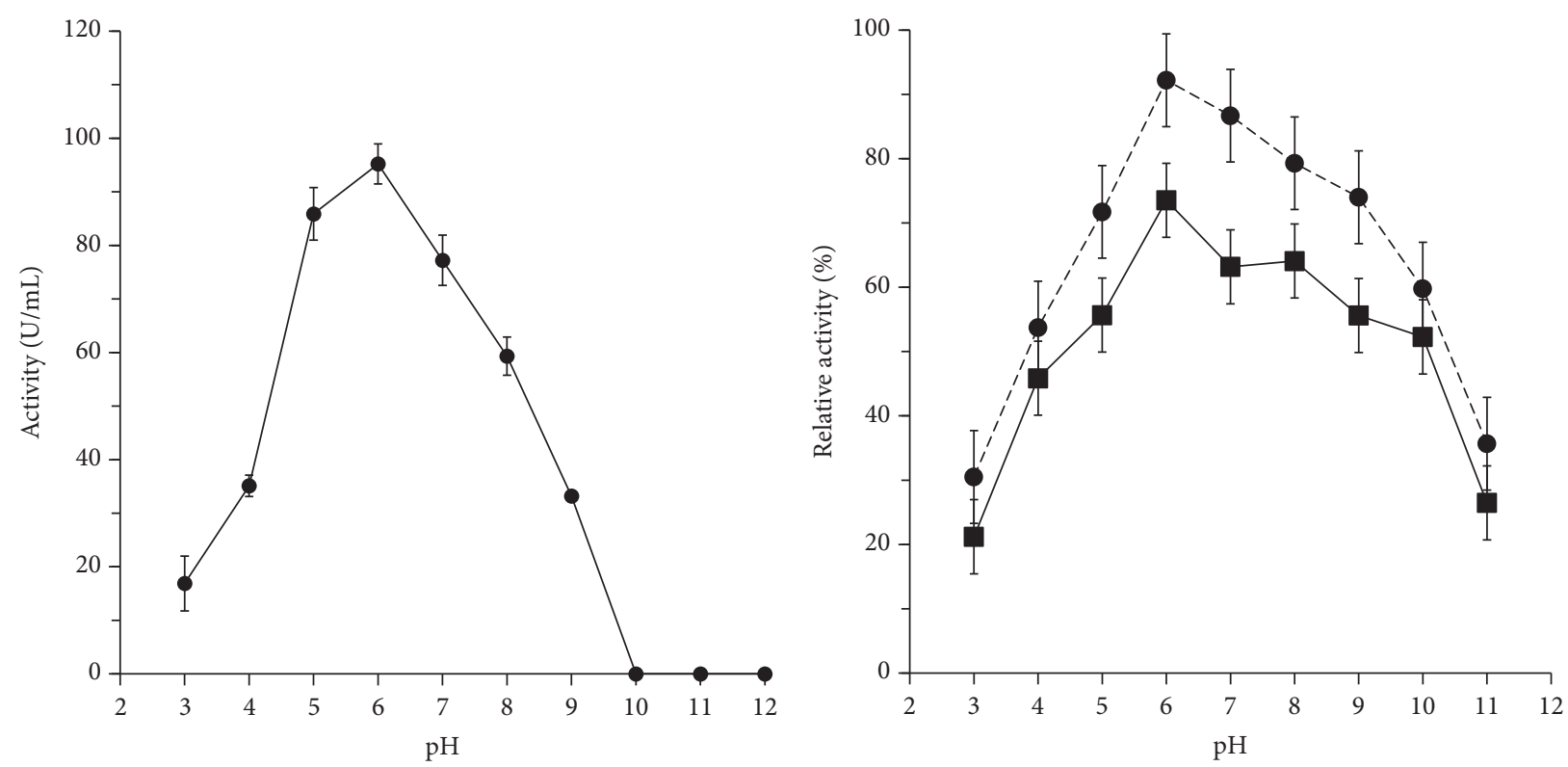

$-30 \mathrm{~min}$

(a)

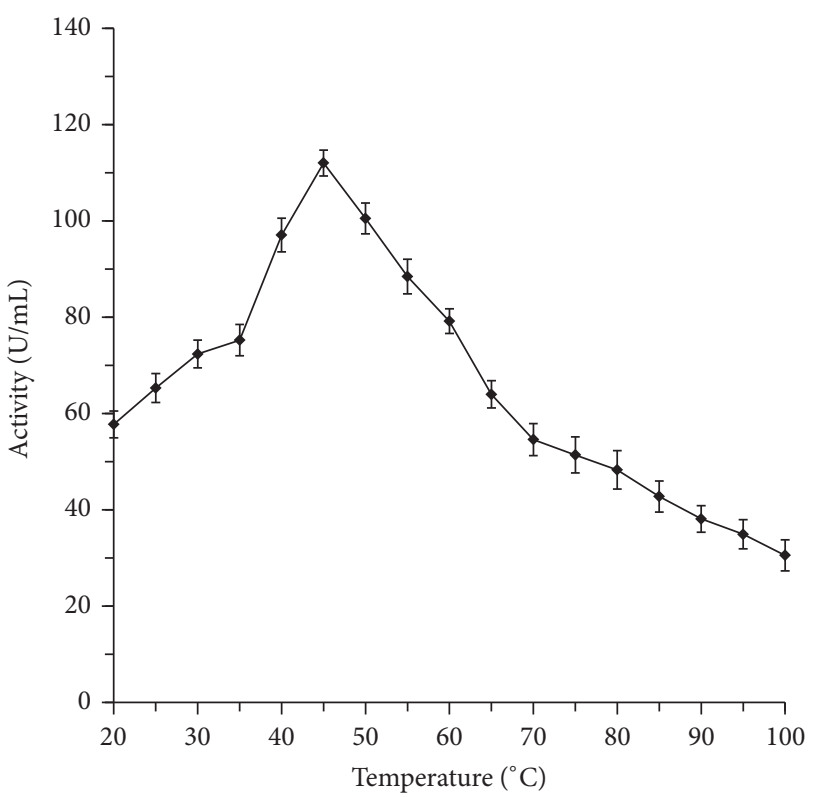

(b)

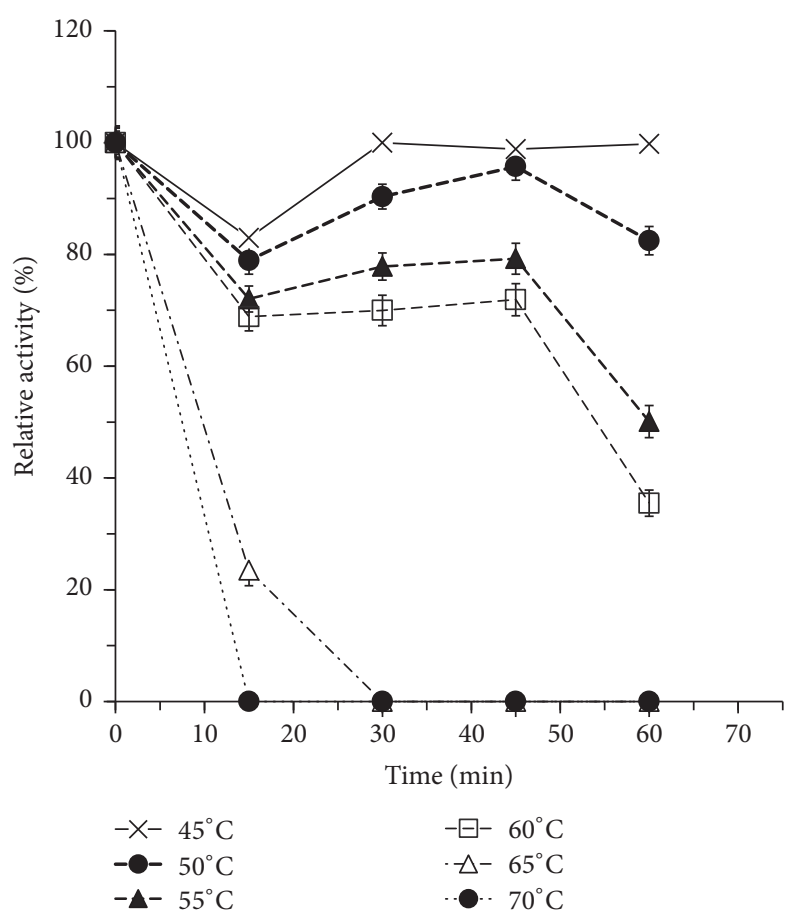

(d)

FIGURE 6: Effects of $\mathrm{pH}$ and temperature on the activity and the stability of the purified $\mathrm{XynA}_{\mathrm{MG} 1}$. (a) Effect of $\mathrm{pH}$ on activity at $\mathrm{pH} 3.0$ to 11.0. The maximum activity was detected at $\mathrm{pH} 5.5$ and was taken as $100 \%$. (b) The $\mathrm{pH}$ stability of $\mathrm{XynA}_{\mathrm{MG1}}$, incubated at $\mathrm{pH} 3.0$ to $\mathrm{pH} 11.0$ for $30 \mathrm{~min}$ and $60 \mathrm{~min}$, at $50^{\circ} \mathrm{C}$. (c) Effect of different temperatures on the activity of $\mathrm{XynA}_{\mathrm{MG} 1}$. The maximum activity was detected at $45^{\circ} \mathrm{C}$. (d) Thermal stability after incubation at $45^{\circ} \mathrm{C}$ to $70^{\circ} \mathrm{C}$ for various times. The data were presented as mean $\pm \mathrm{SD}(n=3)$.

The anionic surfactant SDS which is well-known to cause protein denaturation severely deactivated $\mathrm{XynA}_{\mathrm{MG} 1}$. Many xylanases were known to be strongly affected by SDS. These include xylanase rMxyl from compost-soil metagenome, xylanase from Burkholderia sp. DMAX, Aspergillus awamori
VTCC-F312, and Aspergillus giganteus [9, 38-40]. This indicated that hydrophobic interactions are important in maintaining the structure of $\mathrm{XynA}_{\mathrm{MG} 1}$.

Nonionic surfactants like Triton X-100 and Tween 80 at $2 \mathrm{mM}$ showed mild inhibitory effects. However at $10 \mathrm{mM}$, 


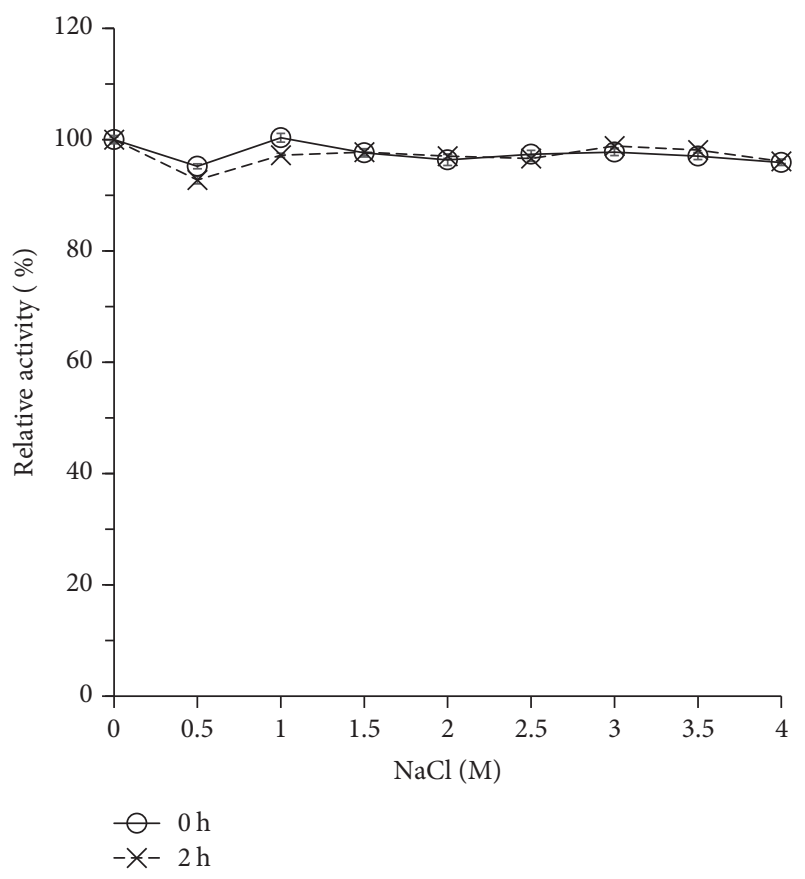

FIgUre 7: Effects of $\mathrm{NaCl}$ on $\mathrm{XynA}_{\mathrm{MG}}$ activity and stability. The xylanase activity at the starting time and without $\mathrm{NaCl}$ added was taken as $100 \%$. The data were presented as mean \pm SD $(n=3)$ (for experimental details, please see the main text).

they slightly enhanced the $\mathrm{Xyn}_{\mathrm{MG}}$ activity which are in good agreement with other recombinant xylanases [41].

3.6. Effects of Sodium Chloride. Purified Xyn $\mathrm{A}_{\mathrm{MG1}}$ showed excellent salt tolerance. While $\mathrm{NaCl}$ was not required for its xylanase activity, $\mathrm{Xyn}_{\mathrm{MG}}$ could function at more than $96 \%$ of its activity in the presence of 1 to $4 \mathrm{M} \mathrm{NaCl}$ for at least $2 \mathrm{~h}$ (Figure 7).

High salt-tolerant and halophilic xylanases have been reported. Recently, a xylanase from Massilia sp. RBM26 isolated from feces of Rhinopithecus bieti was reported to maintain around $86 \%$ activity in $5 \mathrm{M} \mathrm{NaCl}$ for $1 \mathrm{~h}$ [26]. Xylanase from Aspergillus giganteus was shown to tolerate to up to $20 \%$ (3.4 M) of $\mathrm{NaCl}$ [38]. A cold-active xylanase from Glaciecola mesophila KMM 241 exhibited its highest activity at $0.5 \mathrm{M} \mathrm{NaCl}$ and retained $90 \%$ of the activity in $2.5 \mathrm{M} \mathrm{NaCl}$ at its optimal temperature of $30^{\circ} \mathrm{C}$ [35]. A xylanase from a marine bacterium Bacillus subtilis cho40 was reported to be greatly activated to $140 \%$ when preincubated with $0.5 \mathrm{M} \mathrm{NaCl}$ for $4 \mathrm{~h}$ [19]. A cold-active and halo-tolerant Xyn10A xylanase from Bacillus sp. SN5 was reported to exhibit the highest activity (134\%) in $0.5 \mathrm{M} \mathrm{NaCl}$ and retain $90 \%$ activity in $2.5 \mathrm{M}$ $\mathrm{NaCl}$ [42]. In comparison to the above-mentioned xylanases, our $\mathrm{XynA}_{\mathrm{MG} 1}$ reported here has the highest salt-tolerance property.

3.7. Effects of Organic Solvent on Xylanase Xyn $A_{M G 1}$ Activity. The $\mathrm{XynA}_{\mathrm{MG}}$ activity was only slightly affected by common water-miscible organic solvents like acetone, methanol, ethanol, and 1-propanol at the concentration of up to $5 \mathrm{M}$

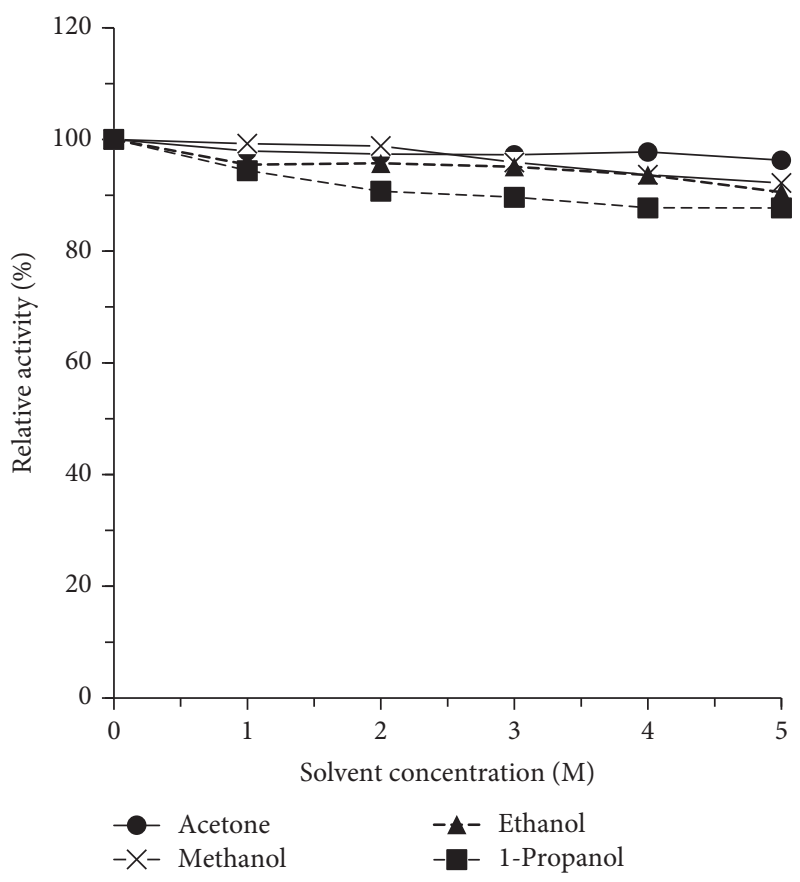

FIGURE 8: Effects of water-miscible organic solvent on $\mathrm{XynA}_{\mathrm{MG} 1}$ xylanase activity and stability. The xylanase activity at the starting time and without organic solvent added was taken as $100 \%$. The data were presented as mean $\pm \mathrm{SD}(n=3)$ (for experimental details, please see the main text).

(Figure 8). At the highest concentration tested (5M), acetone and methanol showed nearly no effect on $\mathrm{Xyn}_{\mathrm{MG1}}$ activity which is similar to the xylanase from Streptomyces rameus L2001 [43]. Comparing among alcohols, 1-propanol and ethanol which have lower polarity index values (and thus more hydrophobic) than methanol slightly inhibited $\mathrm{XynA}_{\mathrm{MG}}$ by $10 \%$ and $14 \%$, respectively. These were similar to those reported for a xylanase (XynA) from Clostridium cellulovorans [44]. Hydrophobic interactions with the dissolved organic solvent molecules seem to be the major factor affecting the protein stability and the enzyme activity in this case [45].

In addition to microbial xylanases mentioned in the above discussions, biochemical properties of bacterial GH10 xylanases especially those from animal intestines are listed in Table 3 for comparison with the $\mathrm{Xyn}_{\mathrm{MG}}$ xylanase described in this study. $\mathrm{XynA}_{\mathrm{MG}}$ is shown to be better tolerance to organic solvent and high salt $(\mathrm{NaCl})$ concentration than other xylanases compared.

\section{Conclusion}

$\mathrm{Xyn}_{\mathrm{MG} 1}$ derived from a chicken cecum metagenome is a new member of the GH10 family xylanase related to the xylanases from Prevotella sp. It is resistant to metal ions, reducing agents, and certain detergents, and highly tolerant to high concentrations of salt and water-miscible organic solvents. These make $\mathrm{XynA}_{\mathrm{MG} 1}$ a potential candidate for applications in the enzymatic processes operated at high 
TABLE 3: Biochemical properties of GH10 xylanases from animal intestinal bacteria compared with XynA $\mathrm{AGl}_{\text {}}$.

\begin{tabular}{|c|c|c|c|c|c|c|c|c|}
\hline \multirow[t]{2}{*}{ Source } & \multirow{2}{*}{$\begin{array}{l}\text { Xylanase } \\
\text { name }\end{array}$} & \multicolumn{2}{|c|}{ Optimal } & \multicolumn{2}{|c|}{$\begin{array}{c}\text { Stability } \\
\text { [residual activity (\%)] }\end{array}$} & \multicolumn{2}{|c|}{$\begin{array}{c}\text { Tolerance } \\
\text { [residual activity (\%)] }\end{array}$} & \multirow[t]{2}{*}{ Reference } \\
\hline & & Temp $\left({ }^{\circ} \mathrm{C}\right)$ & $\mathrm{pH}$ & Temp & $\mathrm{pH}$ & Solvent & $\mathrm{NaCl}$ salt & \\
\hline $\begin{array}{l}\text { Microbacterium } \\
\text { trichothecenolyticum } \\
\text { HY-17 from Gryllotalpa } \\
\text { orientalis gut }\end{array}$ & rXylH & 60 & 9.0 & $55^{\circ} \mathrm{C}, 30 \%$ & $\begin{array}{l}\mathrm{pH} 5.5-10 \\
80 \%\end{array}$ & ND & $\mathrm{ND}$ & {$[46]$} \\
\hline $\begin{array}{l}\text { Paenibacillus macerans } \\
\text { IIPSP3 from termite gut }\end{array}$ & IIPSP3 & 60 & 4.5 & $90^{\circ} \mathrm{C}, 70 \%$ & $\begin{array}{l}\text { pH } 3.5,40 \% \\
\text { pH 9.5, 67\% }\end{array}$ & ND & $\begin{array}{c}10 \mathrm{mM} \\
119 \%\end{array}$ & {$[47]$} \\
\hline $\begin{array}{l}\text { Sphingobacterium sp. } \\
\text { TN19 from Batocera } \\
\text { horsfieldi larvae gut }\end{array}$ & XynA19 & 45 & 6.5 & $40^{\circ} \mathrm{C}, 90 \%$ & ND & ND & $\begin{array}{c}10 \mathrm{mM} \\
95 \%\end{array}$ & {$[48]$} \\
\hline $\begin{array}{l}\text { Cellulosimicrobium sp. } \\
\text { HY-13 from earthworm } \\
\text { gut }\end{array}$ & XylK & 55 & 6.0 & ND & ND & ND & $\mathrm{ND}$ & {$[49]$} \\
\hline $\begin{array}{l}\text { Massilia sp. RBM26 from } \\
\text { Rhinopithecus bieti feces }\end{array}$ & XynRBM26 & 45 & 5.5 & $\begin{array}{c}30-50^{\circ} \mathrm{C} \\
62 \% \\
\end{array}$ & $\begin{array}{c}\text { pH } 5.5-10.0, \\
80 \% \\
\end{array}$ & ND & $5 \mathrm{M}, 86 \%$ & {$[26]$} \\
\hline $\begin{array}{l}\text { Caldicellulosiruptor } \\
\text { bescii from geothermally } \\
\text { heated freshwater pool }\end{array}$ & CbXyn10B & 70 & 7.2 & $\begin{array}{c}60-75^{\circ} \mathrm{C} \\
60 \%\end{array}$ & $\mathrm{pH} 8.0,50 \%$ & ND & $\mathrm{ND}$ & {$[50]$} \\
\hline $\begin{array}{l}\text { Bacteroides xylanisolvens } \\
\text { from human gut }\end{array}$ & $\mathrm{XB1A}$ & 37 & 6.0 & $48^{\circ} \mathrm{C}, 80 \%$ & $\begin{array}{l}\text { pH 9.0, 50\% } \\
\text { pH 5.0, 50\% }\end{array}$ & ND & $\mathrm{ND}$ & {$[51]$} \\
\hline $\begin{array}{l}\text { Chicken gut } \\
\text { metagenome }\end{array}$ & $\mathrm{XynA}_{\mathrm{MG1}}$ & 45 & 6.0 & $60^{\circ} \mathrm{C}, 72 \%$ & $\begin{array}{l}\mathrm{pH} 3,25 \% \\
\mathrm{pH} 8,70 \%\end{array}$ & $\begin{array}{c}5 \mathrm{M} \\
\text { acetone, } \\
98 \% \\
5 \mathrm{M} \\
\text { ethanol, } \\
86 \%\end{array}$ & $4 \mathrm{M}, 96 \%$ & This study \\
\hline
\end{tabular}

$\mathrm{ND}=$ not determined

concentration of salt and organic solvent such as in food and biofuels industries.

The salt-tolerant xylanase property of $\mathrm{XynA}_{\mathrm{MG} 1}$ can be useful in the processing of sea food and food with a high salt content which contain 0.5 to $2.5 \mathrm{M} \mathrm{NaCl}$, such as marine algae, pickles, and sauce [35]. Furthermore, food materials washing, food processing, and fermentation under high salt condition could reduce cost because sterilization is not required [26]. In bakery industry, salt-tolerant $\mathrm{Xyn}_{\mathrm{MG}}$ xylanase has potential applications in increasing the strength of the dough and adding flavor to baked goods [52].

Modern biofuel (bioethanol) production from lignocellulose biomass employs consolidated bioprocess where both the saccharification (enzymatic hydrolysis of cellulose and hemicellulose components to simple sugar) and fermentation steps take place within the same bioreactor, which makes the process more economical [44]. Tolerance to the carried over biomass pretreatment agents (acid, alkali, and inhibitors) and ethanol tolerance have been identified as two key elements for the enzymes in this consolidated process. The biomass saccharification enzymes, including xylanase, must be able to withstand and function well in the presence of 23 to $63 \mathrm{~g} / \mathrm{L}$ (0.5-1.4 M) ethanol produced from the fermentation step. $\mathrm{XynA}_{\mathrm{MG1}}$ can be a potential candidate for this application as it could tolerate up to $5 \mathrm{M}$ ethanol.
$\mathrm{XynA}_{\mathrm{MG1}}$ functions optimally at the temperature and the $\mathrm{pH}$ range of the chicken intestine, its native environment where its gene was retrieved by metagenomic cloning. This xylanase has potential utility in animal feed to improve nutrient digestibility and growth performance for animals, especially broiler chickens and hens [53].

\section{Conflicts of Interest}

The authors declare that there are no conflicts of interest regarding the publication of this article.

\section{Acknowledgments}

Suthep Wiyakrutta was supported by Mahidol University research grant. Hind AL-Darkazali was supported by the Scholarships for International Ph.D. Students, Faculty of Science, and the Research Assistantships for Ph.D. Students, Faculty of Graduate Studies, Mahidol University.

\section{References}

[1] J. L. Adrio and A. L. Demain, "Microbial enzymes: tools for biotechnological processes," Biomolecules, vol. 4, no. 1, pp. 117139, 2014. 
[2] A. Bhardwaj, P. Mahanta, S. Ramakumar, A. Ghosh, S. Leelavathi, and V. S. Reddy, "Emerging role of N- and Cterminal interactions in stabilizing $(\beta / \mathrm{a}) 8$ fold with special emphasis on Family 10 xylanases," Computational and Structural Biotechnology Journal, vol. 2, no. 3, article e201209014, 2012.

[3] O. Adeola and A. J. Cowieson, "Board-invited review: opportunities and challenges in using exogenous enzymes to improve nonruminant animal production," Journal of Animal Science, vol. 89, no. 10, pp. 3189-3218, 2011.

[4] D. Verma and T. Satyanarayana, "Molecular approaches for ameliorating microbial xylanases," Bioresource Technology, vol. 117, pp. 360-367, 2012.

[5] D. Driss, F. Bhiri, M. Siela, R. Ghorbel, and S. E. Chaabouni, "Purification and properties of a thermostable xylanase GH 11 from Penicillium occitanis Pol6," Applied Biochemistry and Biotechnology, vol. 168, no. 4, pp. 851-863, 2012.

[6] A. Gasparic, J. Martin, A. S. Daniel, and H. J. Flint, "A xylan hydrolase gene cluster in prevotella ruminicola B14: sequence relationships, synergistic interactions, and oxygen sensitivity of a novel enzyme with exoxylanase and $\beta$ - $(1,4)$-xylosidase activities," Applied and Environmental Microbiology, vol. 61, no. 8, pp. 2958-2964, 1995.

[7] Y. Gu, Y. Ding, C. Ren et al., "Reconstruction of xylose utilization pathway and regulons in firmicutes," BMC Genomics, vol. 11, no. 1, article 255, 2010.

[8] E. Fierens, S. Rombouts, K. Gebruers et al., "TLXI, a novel type of xylanase inhibitor from wheat (Triticum aestivum) belonging to the thaumatin family," Biochemical Journal, vol. 403, no. 3, pp. 583-591, 2007.

[9] H. Shi, Y. Zhang, X. Li et al., "A novel highly thermostable xylanase stimulated by $\mathrm{Ca}_{2+}$ from thermotoga thermarum: cloning, expression and characterization," Biotechnology for Biofuels, vol. 6, pp. 1-9, 2013.

[10] G. C. Mead, "Microbes of the avian cecum: types present and substrates utilized," Journal of Experimental Zoology, vol. 252, pp. 48-54, 1989.

[11] S. Zhao, J. Wang, D. Bu et al., "Novel glycoside hydrolases identified by screening a chinese holstein dairy cow rumen-derived metagenome library," Applied and Environmental Microbiology, vol. 76, no. 19, pp. 6701-6705, 2010.

[12] M. J. Sergeant, C. Constantinidou, T. A. Cogan, M. R. Bedford, C. W. Penn, and M. J. Pallen, "Extensive microbial and functional diversity within the chicken cecal microbiome," PLoS ONE, vol. 9, no. 3, Article ID e91941, 2014.

[13] Z. Tu, G. He, K. X. Li et al., "An improved system for competent cell preparation and high efficiency plasmid transformation using different Escherichia coli strains," Electronic Journal of Biotechnology, vol. 8, no. 1, pp. 113-120, 2005.

[14] J. Vikramathithan, G. Nirmal Kumar, P. Muthuraman, and K. Srikumar, "Purification and characterization of thermophilic xylanase isolated from the xerophytic-Cereus pterogonus SP," The Protein Journal, vol. 29, no. 7, pp. 481-486, 2010.

[15] H.-C. Zheng, M.-Z. Sun, L.-C. Meng et al., "Purification and characterization of a thermostable xylanase from Paenibacillus sp. NF1 and its application in xylooligosaccharides production," Journal of Microbiology and Biotechnology, vol. 24, no. 4, pp. 489-496, 2014.

[16] G. L. Miller, "Use of dinitrosalicylic acid reagent for determination of reducing sugar," Analytical Chemistry, vol. 31, no. 3, pp. 426-428, 1959.
[17] O. Gallardo, P. Diaz, and F. I. J. Pastor, "Characterization of a Paenibacillus cell-associated xylanase with high activity on aryl-xylosides: a new subclass of family 10 xylanases," Applied Microbiology and Biotechnology, vol. 61, no. 3, pp. 226-233, 2003.

[18] Y. S. Jeong, H. B. Na, S. K. Kim et al., "Characterization of Xyn10J, a novel family 10 xylanase from a compost metagenomic library," Applied Biochemistry and Biotechnology, vol. 166, no. 5, pp. 1328-1339, 2012.

[19] R. Khandeparker, P. Verma, and D. Deobagkar, "A novel halotolerant xylanase from marine isolate Bacillus subtilis cho40: Gene cloning and sequencing," New Biotechnology, vol. 28, no. 6, pp. 814-821, 2011.

[20] N. C. D. A. Guimaraes, M. Sorgatto, S. D. C. Peixoto-Nogueira et al., "Bioprocess and biotechnology: effect of xylanase from Aspergillus niger and Aspergillus flavus on pulp biobleaching and enzyme production using agroindustrial residues as substract," SpringerPlus, vol. 2, no. 1, article 380, pp. 1-7, 2013.

[21] L. da Silva, C. R. F. Terrasan, and E. C. Carmona, "Purification and characterization of xylanases from Trichoderma inhamatum," Electronic Journal of Biotechnology, vol. 18, no. 4, pp. 307313, 2015.

[22] G. C. Pradeep, Y. H. Choi, Y. S. Choi et al., "A novel thermostable cellulase free xylanase stable in broad range of $\mathrm{pH}$ from Streptomyces sp. CS428," Process Biochemistry, vol. 48, no. 8, pp. 1188-1196, 2013.

[23] Z. Gao, L. Ruan, X. Chen, Y. Zhang, and X. Xu, "A novel salttolerant endo- $\beta$-1,4-glucanase Cel5A in Vibrio sp. G21 isolated from mangrove soil," Applied Microbiology and Biotechnology, vol. 87, no. 4, pp. 1373-1382, 2010.

[24] B. Henrissat, I. Callebaut, S. Fabrega, P. Lehn, J.-P. Mornon, and G. Davies, "Conserved catalytic machinery and the prediction of a common fold for several families of glycosyl hydrolases," Proceedings of the National Academy of Sciences of the United States of America, vol. 92, no. 15, pp. 7090-7094, 1995.

[25] M. Roberge, C. Dupont, R. Morosoli, F. Shareck, and D. Kluepfel, "Asparagine-127 of xylanase A from Streptomyces lividans, a key residue in glycosyl hydrolases of superfamily 4/7: kinetic evidence for its involvement in stabilization of the catalytic intermediate," Protein Engineering, vol. 10, no. 4, pp. 399-403, 1997.

[26] B. Xu, L. Dai, J. Li et al., "Molecular and biochemical characterization of a novel xylanase from Massilia sp. RBM26 isolated from the feces of Rhinopithecus bieti," Journal of Microbiology and Biotechnology, vol. 26, no. 1, pp. 9-19, 2015.

[27] M. Biasini, S. Bienert, A. Waterhouse et al., "SWISS-MODEL: modelling protein tertiary and quaternary structure using evolutionary information," Nucleic Acids Research, vol. 42, no. 1, pp. W252-W258, 2014.

[28] X. Gong, R. J. Gruniniger, R. J. Forster, R. M. Teather, and T. A. McAllister, "Biochemical analysis of a highly specific, $\mathrm{pH}$ stable xylanase gene identified from a bovine rumen-derived metagenomic library," Applied Microbiology and Biotechnology, vol. 97, no. 6, pp. 2423-2431, 2013.

[29] T. M. Alvarez, R. Goldbeck, C. R. D. Santos et al., "Development and biotechnological application of a novel endoxylanase family GH10 identified from sugarcane soil metagenome," PLoS ONE, vol. 8, no. 7, article e70014, 2013.

[30] P. W. J. J. Van Der Wielen, S. Biesterveld, S. Notermans, H. Hofstra, B. A. P. Urlings, and F. Van Knapen, "Role of volatile fatty acids in development of the cecal microflora in broiler chickens during growth," Applied and Environmental Microbiology, vol. 66, no. 6, pp. 2536-2540, 2000. 
[31] Y. Takahashi, H. Kawabata, and S. Murakami, "Analysis of functional xylanases in xylan degradation by Aspergillus niger E-1 and characterization of the GH family 10 xylanase XynVII," SpringerPlus, vol. 2, article 447, 2013.

[32] M. L. T. M. Polizeli, A. C. S. Rizzatti, R. Monti, H. F. Terenzi, J. A. Jorge, and D. S. Amorim, "Xylanases from fungi: properties and industrial applications," Applied Microbiology and Biotechnology, vol. 67, no. 5, pp. 577-591, 2005.

[33] C. S. Rupert, "Photoenzymatic repair of ultraviolet damage in DNA. II. formation of an enzyme-substrate complex," The Journal of general physiology, vol. 45, pp. 725-741, 1962.

[34] A. Varga, F. Beáta, É. Gráczer, S. Osváth, A. N. Szilágyi, and M. Vas, "Correlation between conformational stability of the ternary enzyme-substrate complex and domain closure of 3phosphoglycerate kinase," FEBS Journal, vol. 272, no. 8, pp. 1867-1885, 2005.

[35] B. Guo, X.-L. Chen, C.-Y. Sun, B.-C. Zhou, and Y.-Z. Zhang, "Gene cloning, expression and characterization of a new cold-active and salt-tolerant endo- $\beta-1,4$-xylanase from marine Glaciecola mesophila KMM 241," Applied Microbiology and Biotechnology, vol. 84, no. 6, pp. 1107-1115, 2009.

[36] S. Heo, J. Kwak, H.-W. Oh et al., "Characterization of an extracellular xylanase in paenibacillus sp. HY-8 isolated from an herbivorous longicorn beetle," Journal of Microbiology and Biotechnology, vol. 16, no. 11, pp. 1753-1759, 2006.

[37] A. Margolles and C. G. De los Reyes-Gavilán, "Purification and functional characterization of a novel $\alpha$-L-arabinofuranosidase from Bifidobacterium longum B667," Applied and Environmental Microbiology, vol. 69, no. 9, pp. 5096-5103, 2003.

[38] M. B. Fialho and E. C. Carmona, "Purification and characterization of xylanases from Aspergillus giganteus," Folia Microbiologica, vol. 49, no. 1, pp. 13-18, 2004.

[39] S. Mohana, A. Shah, J. Divecha, and D. Madamwar, "Xylanase production by Burkholderia sp. DMAX strain under solid state fermentation using distillery spent wash," Bioresource Technology, vol. 99, no. 16, pp. 7553-7564, 2008.

[40] D. Verma, Y. Kawarabayasi, K. Miyazaki, and T. Satyanarayana, "Cloning, expression and characteristics of a novel alkalistable and thermostablexylanase encoding gene ( Mxyl ) retrieved from compost-soil metagenome," PLoS ONE, vol. 8, no. 1, article e52459, 2013.

[41] M. A. Rahman, Y. H. Choi, G. C. Pradeep et al., "An alkaline and metallo-protein type endo xylanase from Streptomyces sp. CSWu-1," Biotechnology and Bioprocess Engineering, vol. 19, no. 2, pp. 311-319, 2014.

[42] W. Bai, Y. Xue, C. Zhou, and Y. Ma, "Cloning, expression and characterization of a novel salt-tolerant xylanase from Bacillus sp. SN5," Biotechnology Letters, vol. 34, no. 11, pp. 2093-2099, 2012.

[43] X. Li, Y. She, B. Sun et al., "Purification and characterization of a cellulase-free, thermostable xylanase from Streptomyces rameus L2001 and its biobleaching effect on wheat straw pulp," Biochemical Engineering Journal, vol. 52, no. 1, pp. 71-78, 2010.

[44] D. Morrison, J. S. van Dyk, and B. I. Pletschke, "The effect of alcohols, lignin and phenolic compounds on the enzyme activity of Clostridium cellulovorans XynA," Bioresources, vol. 6 , pp. 3132-3141, 2011.

[45] J. L. S. Lemos, E. P. S. Bon, M. D. F. E. Santana, and N. Pereira Jr., "Thermal stability of xylanases produced by Aspergillus awamori," Brazilian Journal of Microbiology, vol. 31, pp. 206-211, 2000 .
[46] K. S. Bae, C. K. Sung, Y. H. Rhee et al., "Novel alkali-tolerant GH10 endo-ß-1, 4-xylanase with broad substrate specificity from Microbacterium trichothecenolyticum HY-17, a gut bacterium of the mole cricket Gryllotalpaorientalis," Journal of Microbiology and Biotechnology, vol. 24, no. 7, pp. 943-953, 2014.

[47] P. Dheeran, N. Nandhagopal, S. Kumar, Y. K. Jaiswal, and D. K. Adhikari, "A novel thermostable xylanase of Paenibacillus macerans IIPSP3 isolated from the termite gut," Journal of Industrial Microbiology and Biotechnology, vol. 39, no. 6, pp. 851860, 2012.

[48] J. Zhou, H. Huang, K. Meng et al., "Molecular and biochemical characterization of a novel xylanase from the symbiotic Sphingobacterium sp. TN19," Applied Microbiology and Biotechnology, vol. 85, no. 2, pp. 323-333, 2009.

[49] D. Y. Kim, M. K. Han, J. S. Lee et al., "Isolation and characterization of a cellulase-free endo- $\beta-1,4$-xylanase produced by an invertebrate-symbiotic bacterium, Cellulosimicrobium sp. HY13," Process Biochemistry, vol. 44, no. 9, pp. 1055-1059, 2009.

[50] J. An, Y. Xie, Y. Zhang et al., "Characterization of a thermostable, specific GH10 xylanase from Caldicellulosiruptor bescii with high catalytic activity," Journal of Molecular Catalysis B: Enzymatic, vol. 117, pp. 13-20, 2015.

[51] C. Mirande, P. Mosoni, C. Béra-Maillet, A. Bernalier-Donadille, and E. Forano, "Characterization of Xyn10A, a highly active xylanase from the human gut bacterium Bacteroides xylanisolvens XB1A," Applied Microbiology and Biotechnology, vol. 87, no. 6, pp. 2097-2105, 2010.

[52] M. S. Butt, M. Tahir-Nadeem, Z. Ahmad, and M. T. Sultan, "Xylanases and their applications in baking industry," Food Technology and Biotechnology, vol. 46, no. 1, pp. 22-31, 2008.

[53] Z. Lei, Y. Shao, X. Yin, D. Yin, Y. Guo, and J. Yuan, "Combination of xylanase and debranching enzymes specific to wheat arabinoxylan improve the growth performance and gut health of broilers," Journal of Agricultural and Food Chemistry, vol. 64, no. 24, pp. 4932-4942, 2016. 

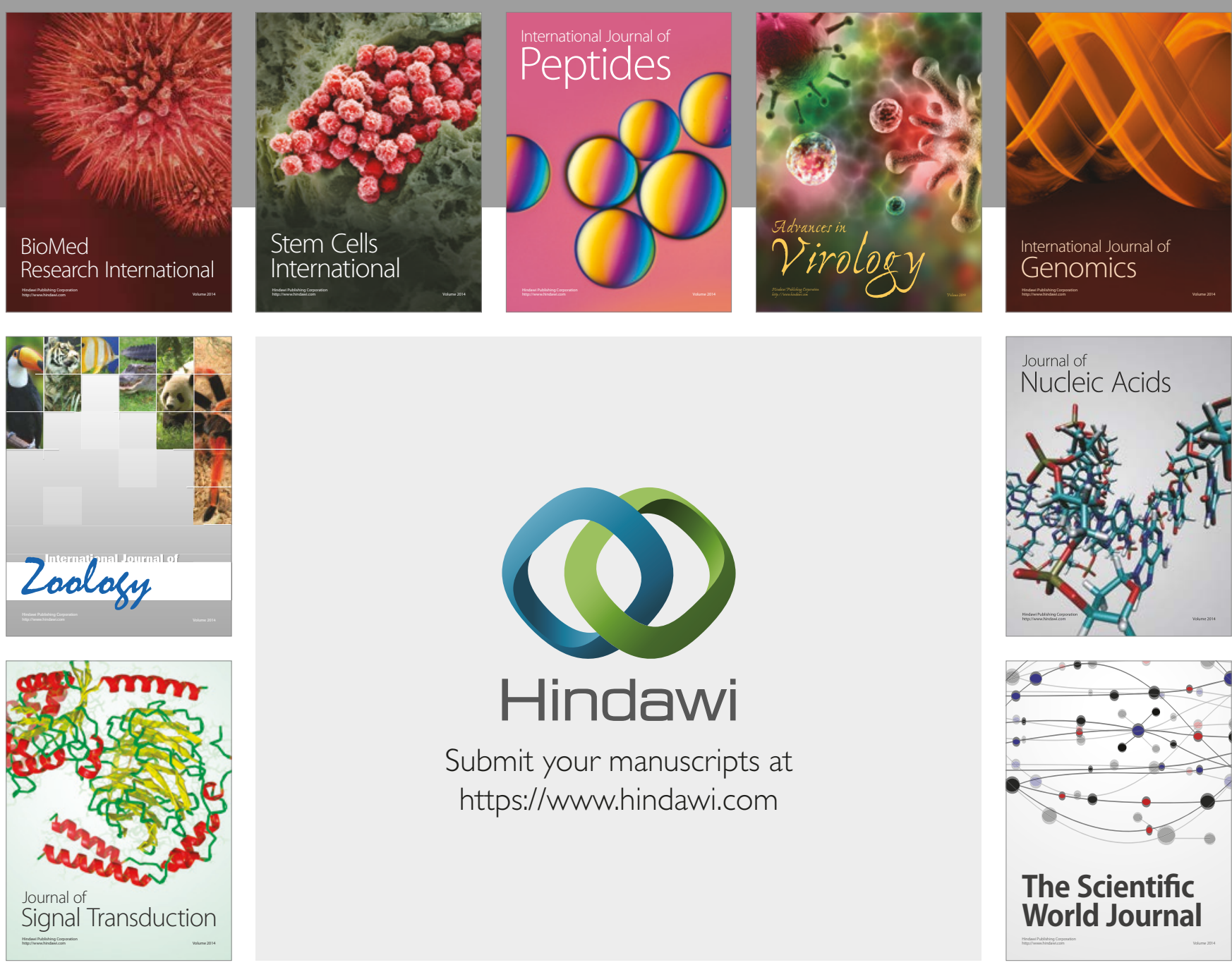

Submit your manuscripts at

https://www.hindawi.com
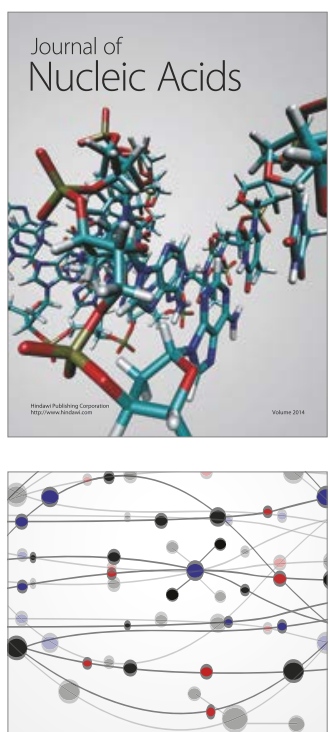

The Scientific World Journal

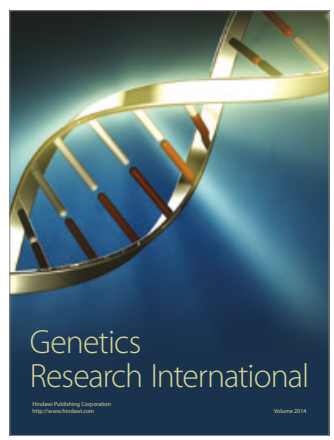

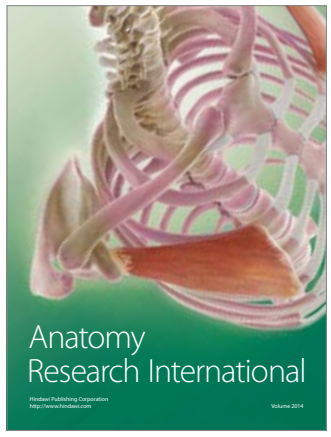

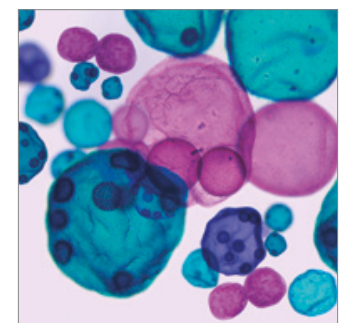

International Journal of Microbiology
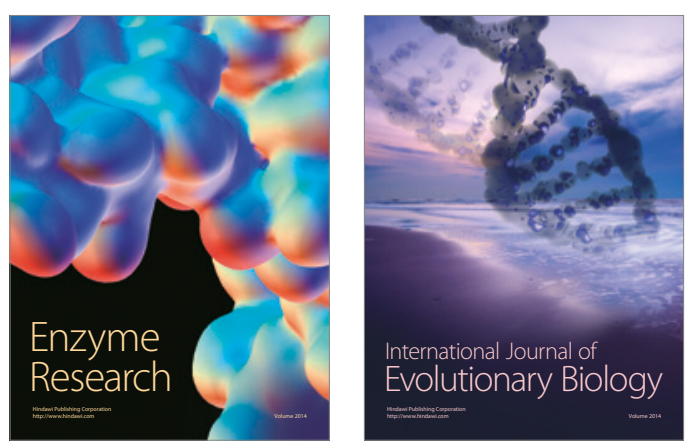
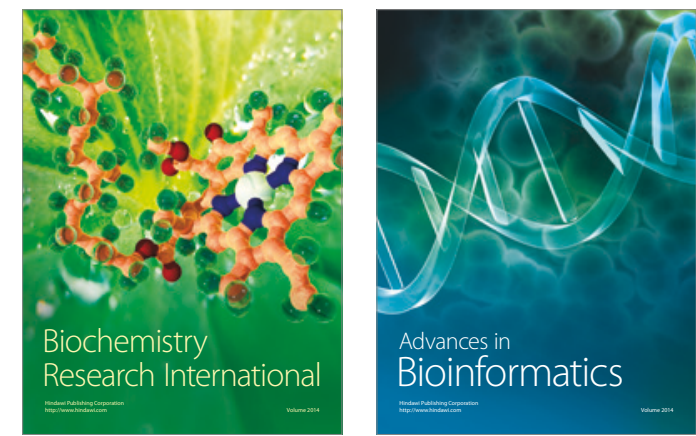

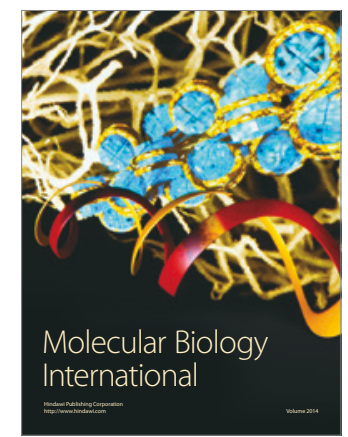

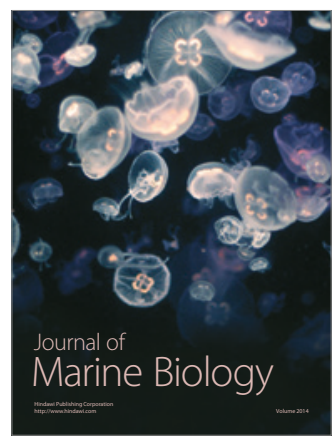

